\title{
Kajian Konservasi Tinggalan Megalitik di Lore, Sulawesi Tengah
}

\author{
Ari Swastikawati, Arif Gunawan dan Yudhi Atmaja \\ Balai Konservasi Borobudur \\ arie_swastik@yahoo.com
}

\begin{abstract}
Abstrak : Salah satu tinggalan megalitik yang memiliki nilai penting sangat tinggi di Indonesia adalah Situs Pokekea, Lore, Sulawesi Tengah, yang berupa patung manusia, kalamba, tutuna (tutup kalamba), dan batu dakon. Namun tinggalan megalitik tersebut sangat tidak terawat dan telah mengalami kerusakan. Untuk mengetahui kondisi tinggalan megalitik tersebut dan cara konservasinya, pada penelitan ini telah dilakukan studi referensi, survei lapangan, serta analisis laboratorium.

Hasil survei lapangan menunjukan lingkungan di Situs Pokekea berupa lembah padang ilalang dengan iklim mikro yang sangat fluktuatif. Dari 24 artefak yang diobservasi, 18 buah artefak berada dalam posisi berdiri di permukaan atau terbenam sebagian dalam tanah, serta 6 artefak lainnya dalam posisi miring atau tidur. Jenis kerusakan dan pelapukan yang dijumpai pada artefak-artefak tinggalan megalitik di Situs Pokekea berupa endapan atau kerak yang berwarna merah, pengelupasan (scaling), retak, pecah, batu yang rapuh, dan batu yang ditumbuhi jasad (algae, lichen, dan moss). Hasil analisis petrografi menunjukan bahwa jenis batuan tinggalan megalitik berupa biotit granit dengan kandungan mineral yang terdiri dari feldspar (plagioklas dan K-feldspar), kuarsa, biotit, dan mineral opak. Hasil analisis fisik menunjukan ada batu jenis biotit granit yang masih bagus, dan namun ada pula yang telah lapuk. Proses kerusakan dan pelapukan tinggalan megalitik di Situs Pokekea disebabkan oleh sifat batu granit sendiri, keberadaan air, fluktuasi suhu dan kelembaban udara yang tinggi. Penanganan kerusakan dan pelapukan pada tinggalan megalitik di Situs Pokekea dapat dilakukan dengan metode konservasi yang bersifat preventive dan active conservation. Preventive conservation dapat berupa pemeliharaan rutin, pengendalian suhu dan kelembaban udara di sekitar batu, mengontrol polusi udara, dan lain sebagainya. Active conservation berupa merestorasi kerusakan dan pelapukan yang telah terjadi pada tinggalan megalitik di Situs Pokekea.
\end{abstract}

Kata kunci : Situs megalitik Lore, Kajian konservasi, Analisis kerusakan/pelapukan

Abtract : One of the megalithic site which has very high significant value in Indonesia is Pokekea site, in Lore, Central Sulawesi. The megalithic objects consist of a human statue, kalamba, tutuna (kalamba cover) and dakon stone. The condition of the megalithic objects currently is undergoing a processes of decay and weathering. Therefore, Borobudur Conservation Office conducted a study to determine methods and techniques for conservation of the objects on Pokekea megalithic site, so it can be technically and archaeologically accepted. The research steps consist of reference study, field surveys, and laboratory analysis .

The results of field surveys indicate the environment conditions at Pokekea site is grassland valley which has very fluctuative microclimate. From 24 artifacts that were observed, shows 18 pieces of artifacts are in a standing position on the surface or partially buried in the soil, while six other artifacts are in a tilted position or sleeping. Damage and weathering type on artefacts found in Pokekea megalithic object are in the form of red deposit or crust, flaking (scaling), cracked, broken, fragile stone and biological growth (algae, lichen, and moss). The petrographic analysis result shows that the objects of a the megalithic rock types is biotite granite, the mineral consists of feldspar (plagioclase and $\mathrm{K}$ - feldspar), quartz, biotite, and opaque minerals. The physical analysis results shows that biotite-granite type stone is in good condition, but and there are some stone that has been weathered. Damage and weathering processes on the Pokekea Site megalithic objects caused by its own granite nature, the presence of water, temperature fluctuations and high humidity. Conservation methods to deal with the damage and weathering of Pokekea site megalithic object are preventive and active conservation. Preventive conservation is an attempt to prevent further damage and decay through regular maintenance, controlling the temperature and humidity in the surrounding object, air pollution control, and other maintenance attemps. While active conservation is conservation treatment to restore damage and weathering that has occurred in the megalithic remains at the site Pokekea .

Keywords : Lore megalithic Site, conservation studies, analysis of damage/weathering

\section{PENDAHULUAN}

\section{A. Latar Belakang}

Tinggalan megalitik adalah tinggalan yang berasal dari zaman prasejarah berupa batu-batu besar. Indonesia merupakan salah satu negara yang kaya 
akan tinggalan megalitik yang tersebar di seluruh wilayah Nusantara. Salah satunya di Taman Nasional Lore Lindu, Sulawesi Tengah yang berada di Lembah Napu, Besoa, dan Bada, berjarak sekitar 150 km dari Kota Palu.

Berdasarkan uji pertanggalan karbon, para peneliti arkeologi memperkirakan tinggalan megalitik di Lore telah ada sejak 2000 tahun sebelum Masehi. Tinggalan megalitik tersebut diperkirakan dahulu berfungsi sebagai patung pemujaan nenek moyang. Selain berfungsi untuk pemujaan, patung ini diduga juga berfungsi sebagai tanda batas daerah kekuasaan. Ada juga yang berpendapat bahwa tinggalan tersebut pada zaman dulu merupakan tempat kuburan komunal dari para kaum bangsawan di wilayah tersebut.

Tinggalan megalitik di Lore terdiri dari empat jenis, yaitu patung berbentuk manusia, kalamba, tutuna (merupakan penutup kalamba) dan batu dakon yang bentuknya tidak beraturan. Kondisi tinggalan megalitik tersebut saat ini terlihat telah mengalami proses kerusakan dan pelapukan, namun data pasti tentang kondisi kerusakan tersebut belum pernah dilaporkan. Demikian juga upaya konservasi belum dilakukan.

Oleh karena itu Balai Konservasi Borobudur melakukan pendataan melalui pengamatan langsung, analisis laboratorium, serta penelusuran pustaka untuk memperoleh informasi tentang metode konservasi yang tepat dan dapat dipertanggungjawabkan dari sisi teknis dan arkeologis.

Permasalahan kerusakan dan pelapukan yang terjadi pada tinggalan megalitik tersebut antara lain:

a) Lokasi tinggalan megalitik tersebut berada di alam terbuka dengan bentang alam berupa lembah. Kondisi cuaca terutama temperatur udara di daerah lembah tersebut sangat fluktuatif, dimana perbedaan suhu pada pagi, siang, dan malam hari sangat tinggi.

b) Sebagian besar artefak berada pada posisi langsung di atas permukaan tanah dan ada pula yang tertanam dalam tanah, sehingga proses pelapukan karena faktor kapilarisasi air lebih cepat.

c) Sebagian besar batu kalamba ketika ditemukan sudah tidak menyatu dengan tutuna, bahkan pada beberapa kalamba tidak ditemukan pasangan batu tutuna-nya, sehingga cekungan batu kalamba tersebut terisi air hujan sepanjang tahun. Oleh karena itu proses pelapukan oleh air hujan terjadi terus menerus. Adanya air kapilarisasi dan air hujan terus menerus menyebabkan tingkat pelapukan batu ini sangat tinggi.

d) Jenis batuan material tinggalan megalitik di Lore kemungkinan berupa batu andesit dan batu granit. Batu andesit dan batu granit merupakan jenis batuan yang relatif tahan terhadap proses pelapukan, tetapi jika sudah mengalami pelapukan maka proses pelapukanya akan lebih cepat. Sebagai contoh batu kalamba yang dipindahkan ke Museum Negeri Palu menjadi lapuk, bahkan jika disentuh akan seperti butiran pasir yang menempel di tangan.

e) Di daerah Lore masih banyak terdapat binatang liar seperi celeng. Masyarakat di sekitar situs masih memelihara binatang ternak seperti sapi dan kerbau yang dipelihara secara liar. Jika binatang-binatang tersebut gatal maka akan menggesek-gesekan badannya pada dinding batu kalamba, sehingga pada beberapa dinding batu kalamba mengalami keausan karena ulah binatang tersebut.

f) Beberapa tinggalan megalitik mengalami kerusakan fisik seperti retak dan pecah. Oleh karena itu perlu dilakukan tindakan perbaikan. Berdasarkan permasalahan kerusakan dan pelapukan yang telah dijabarkan di atas maka diperlukan penanganan atau tindakan konservasi yang tepat baik dari sisi arkeologis maupun teknis.

\section{B. Maksud dan Tujuan}

Maksud dari kajian ini adalah untuk menemukan teknik dan metode konservasi tinggalan megalitik Lore yang tepat, sehingga dapat diterima dari sisi teknis-arkeologis. Sedangkan tujuan dari kajian ini adalah:

1. Megidentifikasi kondisi artefak tinggalan megalitik di Lore, Sulawesi Tengah

2. Mengidentifikasi faktor-faktor penyebab 
kerusakan dan pelapukan tinggalan megalitik di Lore, Sulawesi Tengah.

3. Mengetahui proses kerusakan dan pelapukan yang terjadi pada tinggalan tersebut

4. Membuat rekomendasi untuk penanganan kerusakan dan pelapukan.

\section{Ruang Lingkup}

Kajian konservasi ini dibatasi pada tinggalan megalitik yang berada di Situs Pokekea, Lore Tengah, Sulawesi Tengah.

\section{Landasan Teori}

Asal usul batuan dan deskripsi petrologi material batuan sangat penting diketahui untuk memahami tingkah laku materi dan karakteristiknya, sehingga dapat menentukan tindakan pemeliharaan dan penanganannya untuk mempertahankan keberadaanya sampai jangka panjang. Adapun deskripsi petrologi yang diperlukan meliputi kekerasan permukaaan, porositas, kapilaritas, suhu pemuaian, kandungan air, ukuran pori dan distribusinya, kekuatan mekanik, kecepatan rambat suara, dan ketahanan terhadap kristalisasi garam. Pengambilan foto menggunakan SEM (Scanning Electro Microscope) dan analisis EDX (EnergyDispersive $X$-ray Analysis) juga akan sangat membantu memahami karakteristik material batu tersebut (Doehne and Price, 2010: 1).

\section{METODE PENELITIAN}

Metode penelitian yang digunakan adalah studi referensi, observasi lapangan, dan analisis laboratorium.

1. Studi Referensi

Studi referensi atau studi pustaka dimaksudkan untuk menelusuri dan mendapatkan data serta informasi yang telah didokumentasikan dalam berbagai bentuk, baik laporan, foto, peta, gambar, yang telah disusun dan dibukukan, yang memiliki relevasi dengan kajian ini.

2. Survei Lapangan dan Wawancara

Survei lapangan dilaksanakan untuk memperoleh data mengenai kondisi artefak saat ini dan kondisi iklim mikro di sekitar artefak. Dalam kegiatan survei juga dilakukan wawancara dengan juru pelihara yang seharihari merawat tinggalan megalitik tersebut serta dengan petugas dari instansi terkait seperti Balai Pelestarian Cagar Budaya Gorontalo dan Dinas Kebudayaan Propinsi Sulawesi Tengah.

3. Analisis Laboratorium

Analisis laboratorium yang dilaksanakan baru pada sebatas untuk mengetahui jenis batuan dan sifat air dalam kalamba dari tinggalan mengalitik di Pokekea, Lore, Sulawesi Tengah.

\section{HASIL OBSERVASI LAPANGAN DAN ANALISIS LABORATORIUM}

\section{A. Artefak-Artefak Tinggalan Megalitik Pokekea}

Situs Pokekea memiliki lebih dari 20 artefak tinggalan megalitik yang tersebar tidak merata. Dalam kajian ini tidak dilakukan pengamatan terhadap seluruh artefak, tetapi hanya mengambil beberapa sampel yang mewakili, karena faktor keterbatasan waktu dan dana.

Fokus penelitian tidak pada aspek arkeologinya, tetapi pada aspek konservasi dari artefak-artefak tersebut. Kajian pada tahap ini lebih cenderung untuk

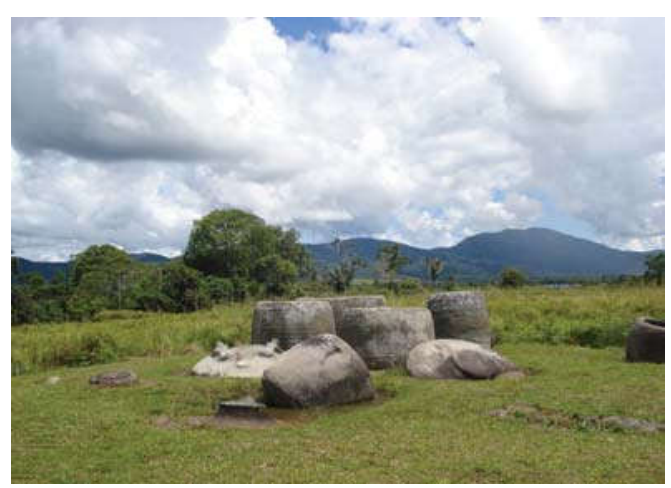

Gambar 1. Artefak tinggalan megalitik di situs Pokekea

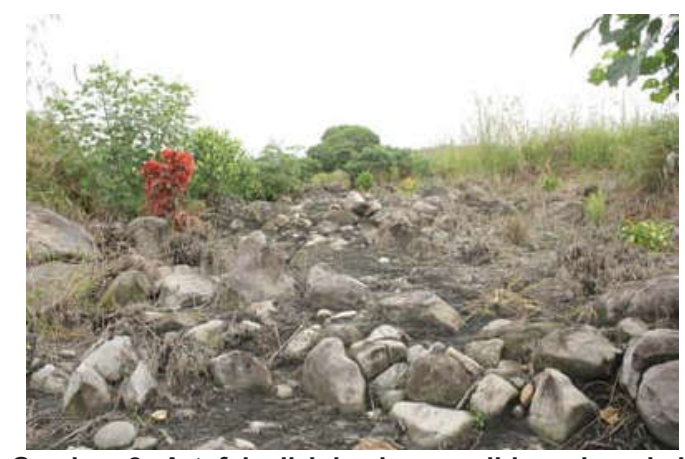

Gambar 2. Artefak di lokasi yang diduga bengke pembuatan batu kalamba di Desa Hangira 


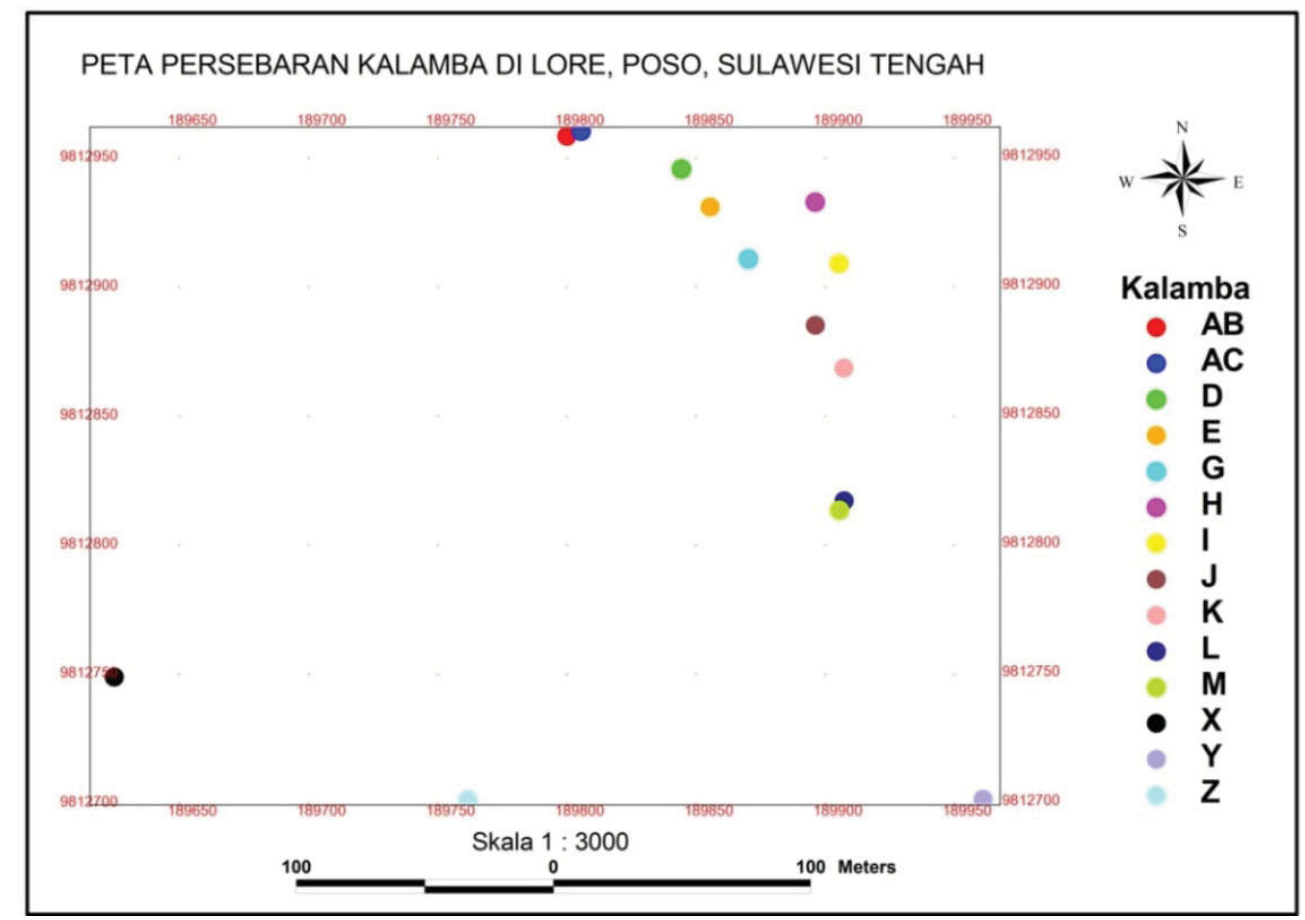

Gambar 3. Peta Persebaran Kalamba di Lore, Poso, Sulawesi Tengah

mengetahui jenis dan karakter batuan, serta mencari penyebab kerusakan dan pelapukan yang terjadi pada tinggalan megalitik Pokekea. Kajian tahap berikutnya akan difokuskan pada penanganan konservasi. Dalam kajian konservasi ini dilakukan observasi terhadap 24 artefak dan pembuatan peta persebaran terhadap 14 artefak yang tersebar di Situs Pokekea seperti terlihat pada Gambar 3. Selain itu juga dilakukan observasi pada situs yang dahulunya diperkirakan menjadi bengkel pembuatan batu kalamba, yang letaknya masih di Desa Hangira. Sebagai informasi tambahan dan pembanding juga dilakukan observasi terhadap 3 buah tinggalan megalitik yang tersimpan di Museum
Negeri Palu yang berada di luar ruangan.

Dua puluh empat artefak tinggalan megalitik yang diobservasi terdiri dari 23 buah batu kalamba dan 1 buah arca. Sedangkan arterfak yang diobservasi di Museum Negeri Palu berupa 1 buah batu kalamba yang sudah rapuh dan 2 buah arca.

\section{B. Kondisi Lingkungan Tinggalan Megalitik Pokekea}

Secara administratif tinggalan megalitik Pokekea berada di lembah Besoa, Desa Hangira, Kecamatan Lore Tengah, Kabupaten Poso, Provinsi Sulawesi Tengah. Situs megalitik Pokekea berupa lembah

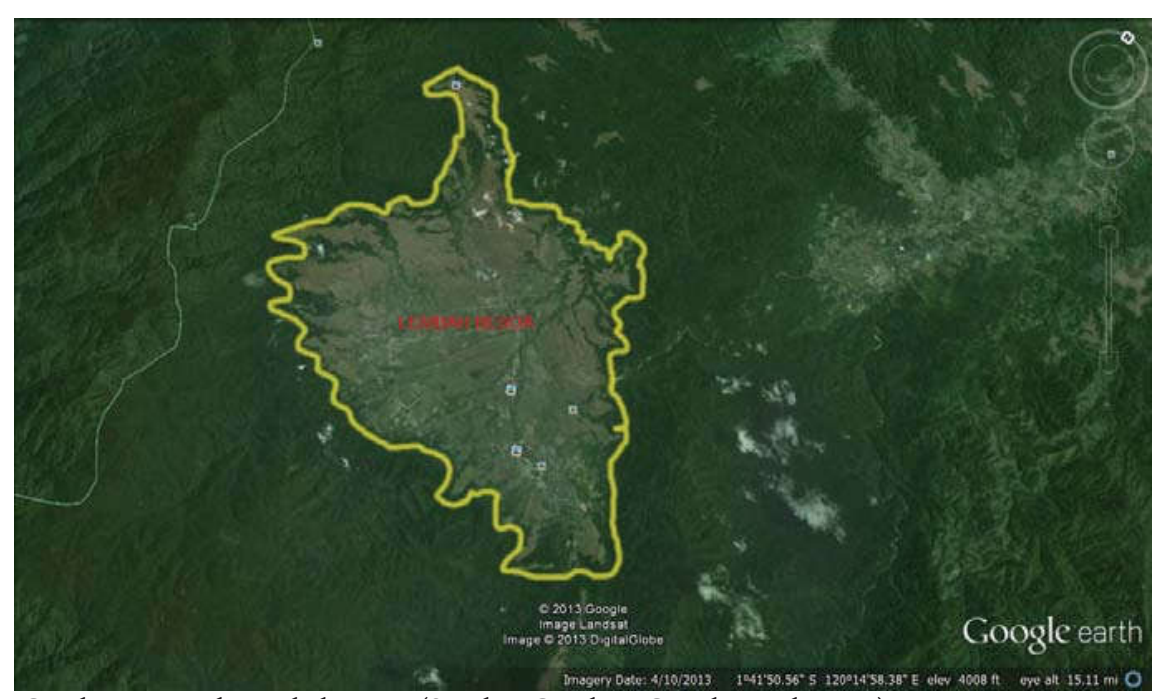

Gambar 4. Letak Lembah Besoa (Sumber Gambar: Google Earth, 2013) 
padang ilalang yang dikelilingi oleh perbukitan dan hutan lindung Taman Nasional Lore Lindu. Pada tepian lembah terdapat aliran sungai yang mengalir mengelilingi lembah. Sumber mata air sungai berada di perbukitan Taman Nasional Lore Lindu.

Vegetasi yang ada di lembah Besoa berupa rumput ilalang yang dikelilingi oleh lahan pertanian padi yang subur, sedikit perkebunan cokelat dan kopi serta hutan hujan tropis yang masih luas. Tipe vegetasi hutan Lore Lindu adalah vegetasi hutan hujan dataran rendah dan hutan hujan pegunungan. Vegetasi hutan hujan pegunungan didominasi oleh kaha (Castanopsis argentea), palili bohe, palili nete, palili pence (Lithocarpus sp), dan berbagai jenis Syzigium. Jenis lain yang tidak umum adalah Podocarpus, Elaeocarpus, Adinandra, Lasiantthus, Cinnamomum, Letsea, Callophylium, dan lain-lain. Vegetasi hutan hujan dataran rendah di Lore Lindu didominasi oleh Mussaendopsis beccariana, Ficus sp., Myristica sp., Pterospermum sp., Canangium odoratum, arenga pinatta, Arenga sp., dan lain-lain. Jenis tumbuhan lain yang ditemukan dalam zona vegetasi ini adalah tahiti (Disoxyllum sp.), uru (Elmerillia atau Manglietia), luluna (Celtis sp.), maro (Garciniasp), kaupahi, dango (Carralia brachiata), palili (Lithocarpus sp.), nuncu (Ficus sp.), tingaloko (Leea sp.), tea uru (Artocarpus sp.), huka (Gnetum gnemon), pangi (Pangium edule), kaumpangana (Ardisia). Di beberapa tempat juga terdapat Vatica sp. (Dipterocarpaceae), Durio zibethinus (durian), Duabanga moluccana (lekotu) dan Octomeles sumatrana (benoang). Vegetasi sekunder yang terbentuk setelah pembukaan ladang berupa berupa rumput-rumputan dan tumbuhan tidak berkayu. Pada tahun kedua atau ketiga, herba penutup ini akan diganti oleh semak belukar yang lebat, yang didominasi oleh walobira (Melastoma malabathricum) dan atau hinduru (Villebrunnea sp.). Jenis pohon yang kelak menggantikan semak belukar ini diantaranya wulaya (Trema orientalis), hinanu (Callicapra), kuo (Alphitonia zizyphoides), paili (Lithocarpus). (Ramadhanil, P., 2002).

Vegetasi di Lembah Besoa sangat berbeda dengan vegetasi hutan di sekitarnya yang didominasi oleh pohon-pohon besar. Menjadi satu pertanyaan

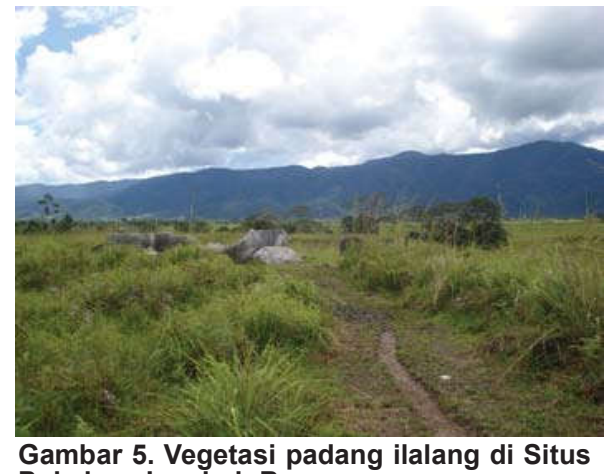
Pokekea, Lembah Besoa

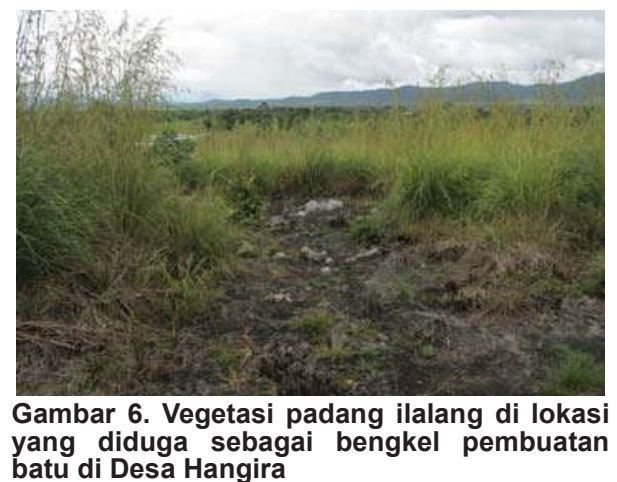

besar, apakah vegetasi di lembah Besoa yang berupa padang ilalang tersebut merupakan vegetasi asli ataukah vegetasi yang terbentuk karena pembukaan lahan.

Secara geografis tinggalan megalitik Pokekea terletak pada 1041'50.56" lintang selatan dan 120014'58.38“ lintang utara, sehingga iklim daerah tersebut masih merupakan iklim tropis, dimana curah hujan relatif tinggi yakni $2000-3000 \mathrm{~mm} /$ tahun. Fluktuasi suhu antara siang dan malam cukup tinggi, saat siang hari sangat panas menyengat tetapi pada malam hari suhu sangat rendah. Hal ini dibuktikan dengan data hasil pencatatan suhu dan kelembaban udara menggunakan datalogger selama 3 hari (Gambar 7) menunjukan suhu terendah $17,34^{\circ} \mathrm{C}$, suhu tertinggi $30,32^{\circ} \mathrm{C}$, sehingga perbedaan suhu siang dan malam

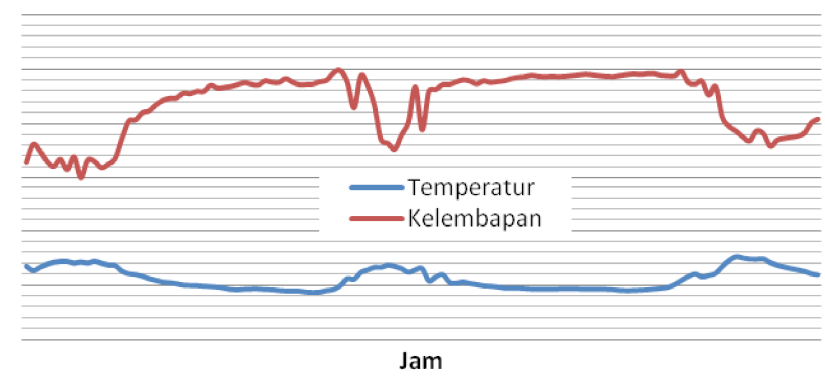

Gambar 7. Grafik temperatur dan kelembaban di situs Pokekea 5 Juli - 7 Juli 2013 
hari (fluktuasi suhu) sebesar $12,98^{\circ} \mathrm{C}$. Begitu juga dengan parameter kelembaban udara, kelembaban udara tertinggi $99,50 \%$ dan kelembaban udara terendah $60,29 \%$, dengan perbedaan kelembaban udara sebesar $39,21 \%$.

Data tersebut menunjukan bahwa kondisi temperatur dan kelembaban udara di lokasi tinggalan megalitik sangat fluktuatif. Kondisi lingkungan yang fluktuatif ini tentu akan sangat berpengaruh terhadap percepatan pelapukan tinggalan megalitik tersebut. Salah satu yang berpengaruh terhadap tingginya fluktuasi suhu adalah kondisi alami lingkungan lembah dan kondisi lingkungan vegetasi di sekitarnya. Sehingga perlu ditelusuri bagaimana kondisi lingkungan, terutama vegetasi saat dahulu tinggalan-tinggalan tersebut ditempatkan dan kondisi lingkungan saat ini.

Hasil penelitian Kirleis, dkk (2012) berdasarkan analisis polen mengatakan bahwa vegetasi yang ada pada lembah Besoa merupakan vegetasi yang sebelumnya merupakan vegetasi hutan hujan. Terjadi perubahan menjadi vegetasi sekunder berupa vegetasi padang seperti saat ini sekitar 2000 tahun yang lalu bersamaan dengan tahap awal konstruksi monumen. Terdapat kecenderungan dinamika vegetasi yang menunjukan bahwa sampai zaman modern telah terjadi pembakaran secara periodik yang menghambat pemulihan hutan hujan pegunungan. Dapat disimpulkan bahwa lingkungan tinggalan megalitik sudah dalam kurun waktu berabad-abad merupakan lingkungan padang ilalang. Oleh karena itu dapat juga ditarik kesimpulan bahwa lingkungan di sekitar tinggalan megalitik telah memiliki suhu yang sangat fluktuatif dalam kurun waktu yang lama. Kondisi ini yang kemungkinan menjadi penyebab terjadinya kerusakan dan pelapukan yang cukup tinggi pada tinggalan megalitik di Situs Pokekea.

\section{Hasil Analisis Petrografi, Fisik, dan Kimia}

Dalam kegiatan penelitian ini dilaksanakan analisis laboratorium yang meliputi analisis petrografi batuan, analisis fisik batuan, dan analisis kimia batuan, serta air tampungan dalam lubang kalamba. Sampel batuan yang dianalisis berasal dari serpihan batu hasil pengelupasan batu kalamba (merupakan material asli) yang terdiri dari sampel dari batu kalamba berkode $A B$ dan $M$ serta sampel batuan yang diambil dari lokasi yang diduga sebagai bengkel pembuatan batu yang berkode SB1 dan SB2. Sampel SB1 mewakili batu kalamba yang sudah rapuh (batu A dan D) sedangkan SB2 mewakili batu kalamba yang belum rapuh. Pertimbangan pemilihan sampel ini didasarkan pada kenampakan secara fisik.

\section{a. Analisis Petrografi dan Fisik}

Analisis petrografi dan fisik bertujuan untuk mengidentifikasi jenis batuan dan sifat fisik batu kalamba. Analisis petrografi dilaksanakan dengan membuat sayatan tipis batuan dan mengamatinya di bawah mikroskop polarisasi. Hasil analisis petrografi dan analisis fisik batuan dapat dilihat di Tabel 1.

Berdasarkan analisis petrografi diketahui bahwa sampel batu kalamba ( $\mathrm{AB}$ dan $\mathrm{M}$ ) maupun batu yang berasal dari lokasi yang diduga bengkel pembuatan tinggalan megalitik (SB1 dan SB2) memiliki komposisi mineral feldspar (plagioklas dan K-feldspar), kuarsa,

Tabel 1. Hasil analisis petrografi dan analisis fisik batuan

\begin{tabular}{|c|c|c|c|c|c|}
\hline \multicolumn{2}{|c|}{ Sampel } & \multirow[t]{2}{*}{ Parameter } & \multirow{2}{*}{\multicolumn{2}{|c|}{ Hasil }} & \multirow[t]{2}{*}{ Keterangan } \\
\hline Kode & Jenis batuan & & & & \\
\hline$A B$ & biotit granit & tidak dilaksanakan & & & sampel habis \\
\hline M & biotit granit & tidak dilaksanakan & & & sampel habis \\
\hline \multirow[t]{4}{*}{ SB 1} & biotit granit & berat jenis & 2,57 & $\mathrm{~g} / \mathrm{cm}^{3}$ & \\
\hline & & densitas & 2,36 & $\mathrm{~g} / \mathrm{cm}^{3}$ & \\
\hline & & porositas & 8,24 & $\%$ & \\
\hline & & $\begin{array}{l}\text { kekerasan } \\
\text { kadar air natural }\end{array}$ & $\begin{array}{l} \pm 6 \\
0,25\end{array}$ & $\begin{array}{l}\text { skala mohs } \\
\%\end{array}$ & \\
\hline \multirow[t]{4}{*}{ SB 2} & biotit granit & berat jenis & 2,62 & $\mathrm{~g} / \mathrm{cm}^{3}$ & \\
\hline & & densitas & 2,53 & $\mathrm{~g} / \mathrm{cm}^{3}$ & \\
\hline & & porositas & 3,56 & $\%$ & \\
\hline & & $\begin{array}{l}\text { kekerasan } \\
\text { kadar air natural }\end{array}$ & $\begin{array}{r} \pm 7 \\
0,11\end{array}$ & $\begin{array}{l}\text { skala mohs } \\
\%\end{array}$ & \\
\hline
\end{tabular}




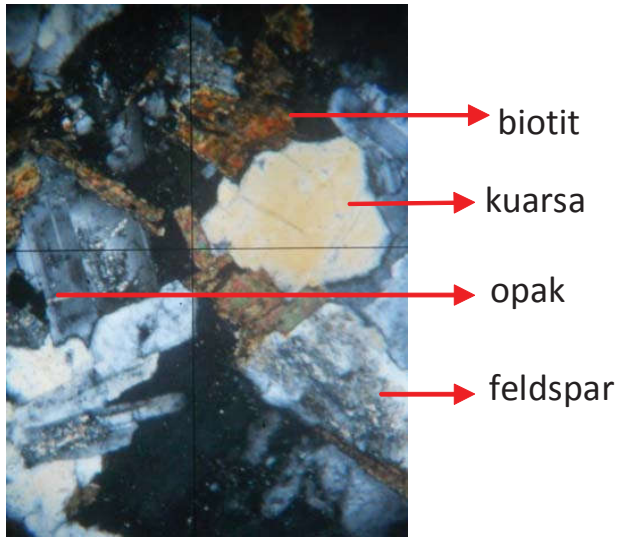

Nikol Silang

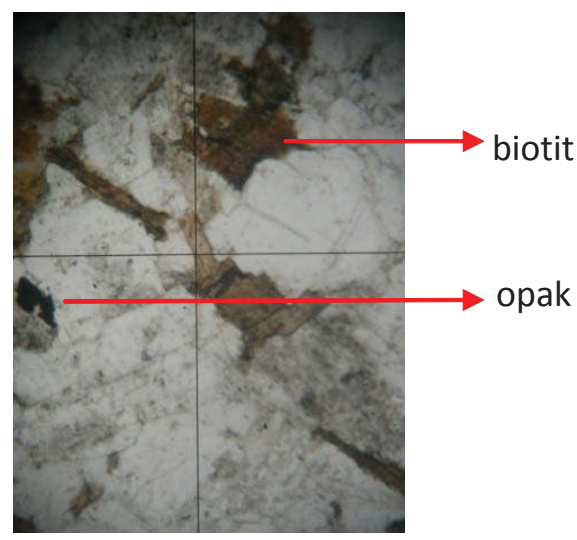

Nikol sejajar

Gambar 8. Penampang mikroskopis sayatan tipis batu kalamba

biotit, dan mineral opak. Kirleis, dkk (2012) mengelompokan sebagai jenis batuan biotit granit. Hasil analisis tersebut dapat menunjukkan bahwa keempat sampel batu berasal dari tempat yang sama, sehingga hasil analisis ini semakin menguatkan dugaan bahwa artefak-artefak batu di Situs Pokekea berasal dari lokasi yang diduga bengkel pembuatan tinggalan megalitik.

Biotit granit berupa batuan beku plutonik berwarna putih kecokelatan, holokristalin, tekstur equigranular, dengan ukuran mineral 0,25 - 2,5 mm bentuk subhedral-anhedral. Komposisi mineral penyusun berupa mineral feldspar (plagioklas dan K-feldspar), kuarsa, biotit, dan mineral opak. Secara kimiawi jenis mineral feldspar terdiri dari kalium feldspar $\left(\mathrm{KAlSi}_{3} \mathrm{O}_{8}\right)$, natrium feldspar $\left(\mathrm{NaAlSi}_{3} \mathrm{O}_{8}\right)$, kalsium feldspar $\left(\mathrm{CaAl}_{2} \mathrm{Si}_{2} \mathrm{O}_{8}\right)$, dan barium feldspar $\left(\mathrm{BaAl}_{2} \mathrm{Si}_{2} \mathrm{O}_{8}\right)$ sedangkan secara mineralogi feldspar dikelompokkan menjadi plagioklas dan ortoklas. Plagioklas merupakan seri suatu larutan padat tersusun dari variasi komposisi natrium feldspar dan kalsium feldspar. Kuarsa, ortoklas (K-Feldspar), dan plagioklas merupakan mineral utama. Mineralmineral tersebut memberikan warna cerah pada granit yang berkisar dari putih sampai merah jambu. Mineral tambahan yang dijumpai dalam granit adalah biotit. Mineral-mineral tersebut berwarna gelap atau hitam sehingga memberikan bintik-bintik hitam pada granit, begitu juga dengan mineral opak. Komposisi mineralogi dan kimiawi batu kalamba dapat dilihat di Tabel 2.

Granit merupakan batuan beku intrusif yang terbentuk di daerah kontinen atau benua. Granit memiliki mineral penyusun dengan butiran kristal yang berukuran kasar. Hal ini menunjukkan bahwa granit terbentuk melalui proses pembekuan magma yang sangat lambat, karena dengan pembekuan magma yang lambat kristal-kristal mineral dapat terbentuk dengan baik sehingga dapat menghasilkan tekstur porfiritik (fanerik granular). Hal ini akan berbeda dengan batuan beku ekstrusif yang mengalami pembekuan secara cepat sehingga kristal-

Tabel 2. Komposisi mineral dan kimia batu Biotit Granit

\begin{tabular}{|c|c|c|}
\hline Jenis mineral & Komposisi kimia & Sifat fisik \\
\hline \multicolumn{3}{|l|}{ Feldspar } \\
\hline - Orthoclase (K-feldspar) & $-\mathrm{KAISi}_{3} \mathrm{O}_{8}$ & $\begin{array}{l}\text { - Orthoclase dicirikan dengan relief } \\
\text { rendah, warna putih berkabut, } \\
\text { berukuran 0,9-2,5mm, bentuk } \\
\text { subhedral-anhedral. }\end{array}$ \\
\hline $\begin{array}{l}\text { Plagioklas (Na-feldspar dan Ca- } \\
\text { feldspar) }\end{array}$ & - $\mathrm{NaAlSi}_{3} \mathrm{O}_{8}$ dan $\mathrm{CaAl}_{2} \mathrm{Si}_{2} \mathrm{O}_{8}$ & $\begin{array}{l}\text { Plagioklas ( } 25 \%) \text {, warna putih } \\
\text { abu-abu, relief rendah-sedang, } \\
\text { ukuran butir } 0,5-2 \mathrm{~mm}\end{array}$ \\
\hline Kuarsa & $-\mathrm{SiO}_{2}$ & $\begin{array}{l}\text { - tidak berwarna, relief rendah, } \\
\text { mineral berukuran } 0,5-2,5 \mathrm{~mm} \text {, } \\
\text { bentuk anhedral. }\end{array}$ \\
\hline Biotit & $-\mathrm{K}(\mathrm{Mg}, \mathrm{Fe})_{3}\left(\mathrm{AlSi}_{3} \mathrm{O}_{10}\right)(\mathrm{OH})_{2}$ & - cokelat, belahan satu arah \\
\hline Mineral opak & - tidak teridentifikasi & $\begin{array}{l}\text { - hitam, kedap cahaya, relief } \\
\text { sangat tinggi, anhedral, } \\
\text { berukuran } 0,25-0,6 \mathrm{~mm} \text {, hadir } \\
\text { setempat - setempat dalam } \\
\text { sayatan. }\end{array}$ \\
\hline
\end{tabular}




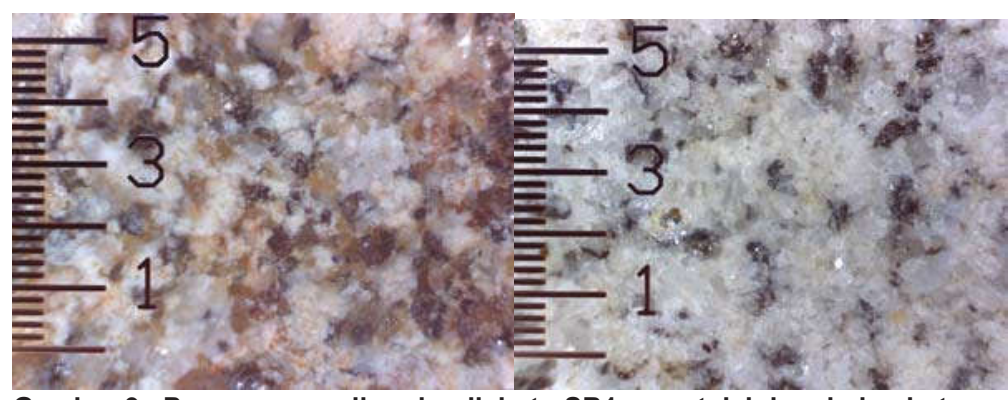

Gambar 9. Penampang mikroskopik batu SB1 yang telah lapuk dan batu SB2 yang belum lapuk

Tabel 3. Hasil analisis sifat fisik batu

\begin{tabular}{lccc}
\multicolumn{1}{r}{ Parameter } & SB1 & SB 2 & Satuan \\
\hline Berat jenis & 2,57 & 2,62 & $\mathrm{~g} / \mathrm{cm}^{3}$ \\
Densitas & 2,36 & 2,53 & $\mathrm{~g} / \mathrm{cm}^{3}$ \\
Porositas & 8,24 & 3,56 & $\%$ \\
Kekerasan & \pm 6 & \pm 7 & skala mohs \\
Kadar air natural & 0,25 & 0,11 & $\%$
\end{tabular}

kristal yang berukuran kasar jarang terbentuk. Sebagai batuan intrusif, granit terbentuk karena pembekuan magma yang terjadi jauh di dalam bumi, yang dalam pembentukannya dapat memotong batuan yang berumur lebih tua. Dijumpainya granit di permukaan bumi sekarang menunjukkan bahwa kerak bumi telah mengalami proses tektonik maupun erosi.

Hasil analisis fisik pada sampel batu yang diambil dari lokasi yang diduga bengkel kalamba (SB1 dan SB2) menunjukan bahwa terdapat perbedaan yang mencolok pada parameter porositas, berat jenis, densitas, kekerasan, dan kadar air natural (lihat Tabel 3). Sampel SB1 mewakili batu kalamba yang sudah rapuh (batu kalamba yang ada di Museum Negeri Palu atau kode batu A dan batu kalamba di Situs Pokekea kode D) sedangkan SB2 mewakili batu kalamba yang belum rapuh. Porositas dan kandungan air natural batu SB1 lebih besar dari batu SB2, sedangkan parameter kekerasan, berat jenis dan densitas batu SB2 lebih besar dibandingkan batu SB1. Perbedaan itu juga terlihat jelas pada penampang mikroskopik batu SB1 dan SB2 (Gambar 9) yang menunjukkan pada batu SB 1 telah terlihat warna cokelat. Warna cokelat tersebut kemungkinan merupakan mineral lempung atau clay sebagai hasil dekomposisi mineral feldspar. Dapat disimpulkan bahwa batu SB1 sudah mengalami pelapukan lebih lanjut dibandingkan dengan batu SB2. Hal ini didasarkan pada penjelasan sebelumnya bahwa kedua batu merupakan jenis batu yang sama yakni biotit granit dan berasal dari lokasi yang sama pula. Dapat disimpulkan bahwa di Situs Pokekea terdapat tinggalan megalitik berbahan batu biotit granit yang berasal dari lokasi sama, tetapi sifat fisik batu-batu tersebut dapat berbeda karena terdapat batu yang telah mengalami proses pelapukan.

\section{b. Analisis Kimia Komposisi Unsur Batuan dan Air} dalam Lubang Kalamba

Hasil analisis kimia komposisi unsur sampel pengelupasan batu kalamba, sampel endapan dalam lubang kalamba, dan sampel tanah yang diambil dari tanah di Situs Pokekea ditunjukkan dalam Tabel 4. Hasil analisis sampel endapan tanah dari lubang kalamba menunjukkan unsur yang dominan adalah silica sebesar 60-85\%. Jika dibandingkan dengan komposisi unsur tanah yang berkisar antara 37-42\%, maka dapat disimpulkan bahwa endapan yang terdapat pada lubang kalamba tidak sepenuhnya berasal dari tanah tetapi juga berasal dari hasil pelapukan batu kalamba. Endapan silikat dapat terbentuk dari hasil pelapukan feldspar yaitu kaolinit dan asam kersik. Proses ini dapat terjadi secara kimiawi (hidrolisis) atau secara fisis (pengelupasan) yang terendapkan. Pemahaman terhadap proses tersebut dapat dilihat secara kuantitatif dari seluruh unsur kimiawi sampel pengelupasan yang nilainya tidak jauh berbeda dengan unsur kimiawi sampel endapan. Tanah kehitaman dengan ciri unsur silika yang rendah adalah tanah lanau, sedangkan tanah kuning yang unsur silikanya lebih besar adalah tanah lempung pasiran. Tanah ini 
Tabel 4. Hasil analisis kimia komposisi unsur

\begin{tabular}{|c|c|c|c|c|c|c|c|c|}
\hline \multirow{2}{*}{ No } & \multirow{2}{*}{ Nama Sampel } & \multicolumn{7}{|c|}{ Parameter (\%) } \\
\hline & & $\mathrm{Ca}$ & $\mathrm{Mg}$ & $\mathrm{Fe}$ & $\mathrm{Al}$ & $\mathrm{CO}_{3}$ & $\mathrm{SiO}_{2}$ & $\mathrm{SO}_{4}$ \\
\hline 1 & ENDAPAN di dalam D & 1.00 & 1.46 & 2.12 & 2.66 & 3.75 & 85.96 & 0.00 \\
\hline 2 & ENDAPAN di dalam $R$ & 1.00 & 0.85 & 2.79 & 2.26 & 4.13 & 84.87 & 0.00 \\
\hline 3 & ENDAPAN di dalam $\mathrm{K}$ & 0.84 & 0.51 & 3.75 & 1.79 & 3.60 & 64.12 & 0.00 \\
\hline 4 & ENDAPAN di dalam H & 0.96 & 0.97 & 3.40 & 2.93 & 3.40 & 60.42 & 0.00 \\
\hline 5 & Tanah Kehitaman & 1.28 & 0.58 & 3.75 & 3.83 & 3.87 & 37.20 & 0.00 \\
\hline 6 & Tanah Kuning & 1.44 & 1.09 & 4.22 & 3.85 & 3.68 & 42.21 & 0.00 \\
\hline 7 & Pengelupasan (E) & 1.20 & 1.31 & 1.21 & 1.58 & 3.52 & 82.61 & 0.00 \\
\hline 8 & Pengelupasan (AB) & 0.84 & 1.53 & 1.25 & 3.85 & 3.57 & 63.24 & 0.00 \\
\hline 9 & Pengelupasan $\mathrm{K}$ & 1.80 & 0.61 & 0.89 & 1.55 & 3.56 & 76.15 & 0.00 \\
\hline 10 & Pengelupasan M & 0.96 & 3.50 & 7.24 & 4.07 & 4.23 & 33.46 & 0.00 \\
\hline 11 & Pengelupasan $\mathrm{H}$ & 0.00 & 1.02 & 1.25 & 3.57 & 4.58 & 94.08 & 0.00 \\
\hline
\end{tabular}

Tabel 5. Hasil analisis kimia air dalam lubang kalamba

\begin{tabular}{|c|c|c|c|c|c|c|c|}
\hline \multirow{2}{*}{ No } & \multirow{2}{*}{ Analisis Air } & \multicolumn{6}{|c|}{ Parameter (ppm) } \\
\hline & & $\mathrm{Ca}$ & $\mathrm{Mg}$ & $\mathrm{Al}$ & $\mathrm{Fe}$ & $\mathrm{SO}_{4}$ & $\mathrm{pH}$ \\
\hline 1 & Air di $F$ & 0.016 & 0.029 & 0.016 & 0.346 & 0.019 & 7.5 \\
\hline 2 & Air di $\mathrm{E}$ & 0.072 & 0.058 & 0.037 & 0.755 & 0.057 & 7.16 \\
\hline 3 & Air di $\mathrm{H}$ & 0.024 & 0.012 & 0.043 & 0.027 & 0.019 & 6.49 \\
\hline 4 & Air di D & 0.024 & 0.012 & 0.032 & 0.033 & 0.019 & 8.11 \\
\hline 5 & Air di $A B$ & 0.024 & 0.014 & 0.032 & 0.045 & 0.019 & 8.29 \\
\hline 6 & Air Sungai & 0.024 & 0.024 & 0.037 & 0.047 & 0.00 & - \\
\hline
\end{tabular}

sebenarnya adalah tanah sedimen yang tertranportasi oleh aliran air. Berdasarkan hasil analisis tersebut memperjelas bahwa seluruh artefak telah mengalami pelapukan secara kimiawi maupun fisis.

Hasil analisis komposisi kimia air dalam lubang kalamba menunjukan secara kuantitatif nilai unsur kimiawi seluruh sampel hanya kecil. Unsur-unsur tersebut kemungkinan berasal dari dekomposisi mineral yang terdapat pada batuan. Hal ini didasarkan bahwa air hujan murni tidak mengandung logam besi $(\mathrm{Fe})$, alumunium $(\mathrm{Al})$, dan mangan $(\mathrm{Mg})$. Air hujan mengandung $\mathrm{SO}_{4}$ dan $\mathrm{CO}_{3}$ jika di daerah tersebut terjadi pencemaran udara. Hasil analisis air dalam lubang kalamba sudah mengindikasikan adanya proses pelapukan pada batuan, sekalipun masih rendah. Selama kandungan unsur kimia air dalam kalamba masih relatif kecil dan $\mathrm{pH}$ netral, maka resiko proses pelapukan batuan secara kimiawi masih rendah. Namun bila terjadi kenaikan $\mathrm{pH}$ seperti pada sampel $\mathrm{D}$ dan $\mathrm{AB}$, akan berpeluang terjadi pelapukan secara kimiawi yang lebih tinggi. Apabila keberadaan air ini dikaitkan dengan hasil analisis material batu dan endapan tersebut di atas, maka sampel yang mempunyai $\mathrm{pH}$ netral $(\mathrm{E}$ dan $\mathrm{H})$ pelapukan yang terjadi adalah proses fisis sedangkan pada sampel D dan $\mathrm{AB}$ pelapukan yang terjadi proses kimiawi.

\section{Kondisi Fisik Tinggalan Megalitik Pokekea}

Dalam kajian ini dilakukan observasi terhadap artefak-artefak meliputi: posisi artefak, dimensi artefak, jenis kerusakan dan pelapukan yang terjadi pada artefak, kandungan air permukaan, dan daya serap (kapilarisasi) batuan terhadap air. Uraian lebih detil disampaikan dalam sub bab sebagai berikut:

a. Posisi Artefak-Artefak Tinggalan Megalitik di Situs Pokekea

Berdasarkan hasil observasi dari 24 artefak, 18 buah artefak berada pada posisi berdiri di permukaan tanah ataupun terbenam sebagian dalam tanah. Bagian yang terbenam dalam tanah kurang lebih 5 sampai 20\% dari tingginya, bahkan terdapat artefak yang terbenam hampir 100\% dari total tingginya seperti pada Gambar 10, 11, 12. Artefak lainnya yang 


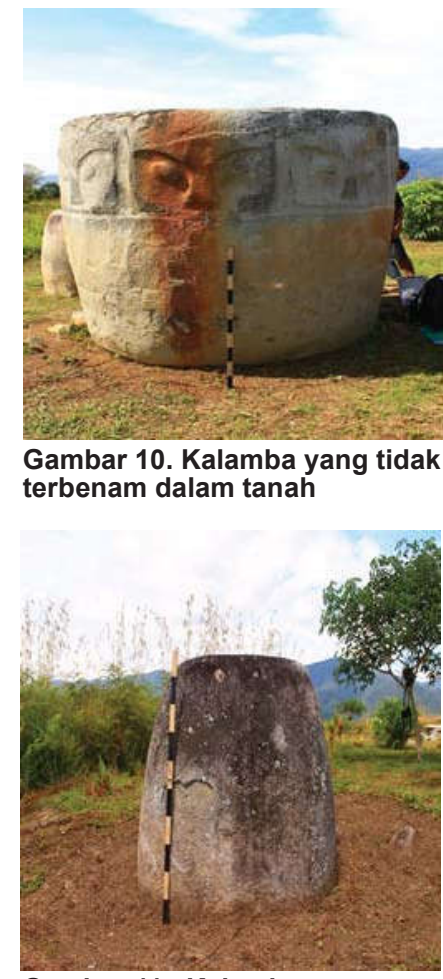

Gambar 11. Kalamba yang terbenam dalam tanah setinggi $29 \mathrm{~cm}$

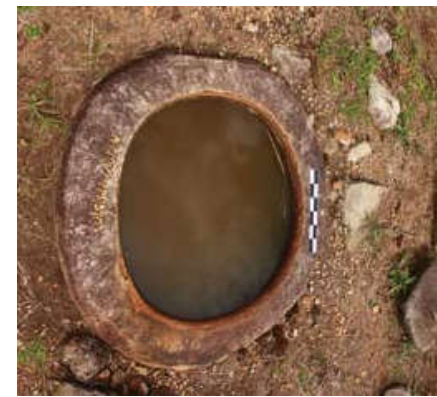

Gambar 12. Kalamba hampir seluruhnya yang terbenam dalam tanah dalam tanah

diobservasi berada pada posisi miring atau tidur, seperti dalam Gambar 13.

Hasil observasi tersebut memperlihatkan bahwa beberapa batu kalamba tidak berada pada posisi semula atau posisi sebenarnya. Hal ini didasarkan pada hasil penelitian arkeologi terdahulu yang menyatakan bahwa batu kalamba memiliki fungsi sebagai wadah penguburan secara komunal. Oleh karenanya posisi asli batu-batu kalamba tersebut berada dalam keadaan berdiri dan berada di atas permukaan tanah. Namun saat ini pengembalian kalamba-kalamba tersebut ke posisi semula dengan pertimbangan aspek arkeologi maupun konservasi kurang memungkinkan. Hal ini karena mengembalikan kalamba pada posisi semula dapat menyebabkan kerusakan. Sebagai contoh

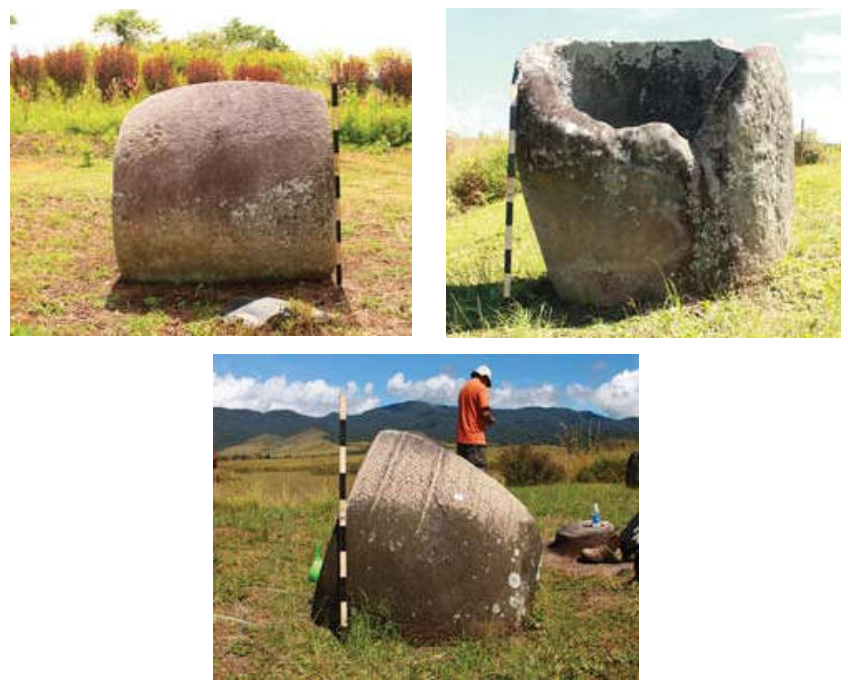

Gambar 13 Beberapa batu kalamba pada posisi miring atau tidur
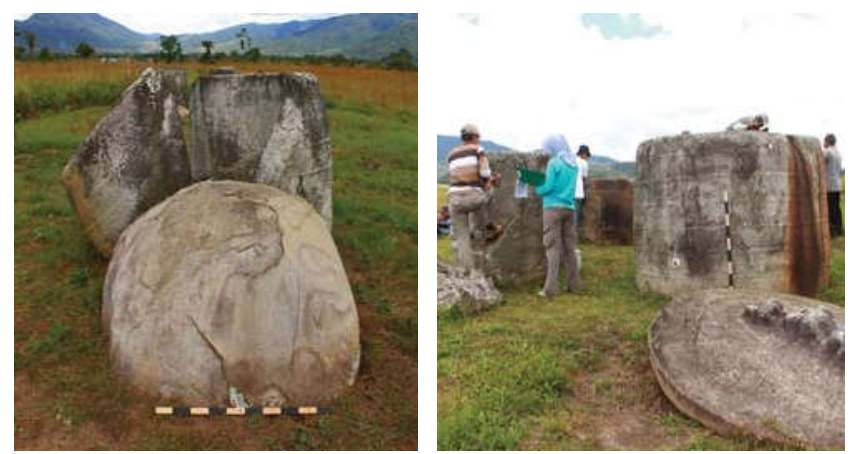

Gambar 14. Batu kalamba yang masih memiliki tutuna

kalamba yang berada pada posisi terbenam dalam tanah justru dalam kondisi lingkungan yang lebih stabil dibandingkan kalamba yang ada di atas tanah.

Sementara itu kalamba yang pada posisi miring dan beresiko jatuh lebih baik dikembalikan pada posisi berdiri (meskipun kalamba dalam posisi berdiri beresiko menjadi tempat tampungan air hujan). Selanjutnya perlu dipertimbangkan apakah dari aspek arkeologi memungkinkan untuk mengembalikan tutuna (penutup kalamba) pada pasangan kalambanya, sehingga beberapa kalamba yang masih memiliki tutuna tidak menjadi tempat tampungan air hujan. Beberapa kalamba pada bagian bawah atau di sampingnya ditemukan tutuna, seperti pada Gambar 14.

\section{b. Jenis Kerusakan dan Pelapukan}

Jenis kerusakan dan pelapukan yang dijumpai pada artefak-artefak tinggalan megalitik di Situs Pokekea berupa endapan atau kerak yang berwarna merah, pengelupasan (scaling), retak, pecah, batu yang 
Tabel 6. Jenis kerusakan dan pelapukan pada tinggalan megalitik di Situs Pokekea

\begin{tabular}{llc}
\multicolumn{1}{c}{ Jenis Kerusakan/pelapukan } & \multicolumn{1}{c}{ Kode artefak/batu } & $\begin{array}{c}\text { Persentase } \\
(\%)\end{array}$ \\
\hline Endapan merah & $\mathrm{E}, \mathrm{H}, \mathrm{U}, \mathrm{AC}$ & 17 \\
\hline Pengelupasan & $\mathrm{C}, \mathrm{E}, \mathrm{F}, \mathrm{H}, \mathrm{I}, \mathrm{J}, \mathrm{M}, \mathrm{O}, \mathrm{Q}, \mathrm{R}, \mathrm{S}, \mathrm{W}, \mathrm{X}, \mathrm{AB}$ & 58 \\
\hline Pertumbuhan organisme & $\mathrm{D}, \mathrm{F}, \mathrm{H}, \mathrm{I}, \mathrm{J}, \mathrm{K}, \mathrm{L}, \mathrm{M}, \mathrm{N}, \mathrm{O}, \mathrm{P}, \mathrm{Q}, \mathrm{S}, \mathrm{U}, \mathrm{V}, \mathrm{W}, \mathrm{X}, \mathrm{AA}, \mathrm{AC}$ & 79 \\
Retak & $\mathrm{D}, \mathrm{E}, \mathrm{G}, \mathrm{H}, \mathrm{J}, \mathrm{K}, \mathrm{M}, \mathrm{O}, \mathrm{T}, \mathrm{AA}$ & 42 \\
\hline Pecah & $\mathrm{M}, \mathrm{O}, \mathrm{T}$ & 13 \\
Rapuh & $\mathrm{A}, \mathrm{D}$ & 8
\end{tabular}

rapuh dan batu yang ditumbuhi jasad algae, lichen, dan moss (data lebih lengkap lihat Tabel 6).

Berdasarkan tabel tersebut diketahui bahwa pada 24 artefak yang diobservasi, pertumbuhan organisme merupakan penyebab yang mendominasi gejala kerusakan dan pelapukan, yang diikuti oleh pengelupasan, retak, endapan atau kerak yang berwarna merah, pecah dan rapuh.

\section{Pertumbuhan Organisme}

Hasil observasi menunjukan bahwa hampir seluruh permukaan artefak batu pada tinggalan megalitik di Situs Pokekea ditumbuhi organisme. Jenis organisme yang dijumpai tumbuh pada permukaan batu adalah algae, lichen dan moss. Algae paling banyak tumbuh pada permukaan batu, yang kedua lichen dan hanya satu kalamba yang ditumbuhi moss, itupun hanya pada bagian bawah.

Algae, lichen dan moss merupakan tumbuhan bertalus yang tubuhnya belum terdiferensiasi menjadi akar, batang dan daun. Algae merupakan jasad yang dapat tumbuh dimana-mana, walaupun di tempat tersebut tidak berlimpah unsur hara dan kering, terutama jenis algae cyanophyta. Algae dapat berupa organisme uniseluller maupun multiseluller yang membentuk koloni. Beberapa kelompok algae dapat tumbuh dan berada dalam batu tergantung pada iklim dan jenis batu. Algae hijau (terkadang berwarna merah, misalnya trentepoblia) diatom (biasanya kuning sampai cokelat), dan algae merah jarang terjadi. Cyanobacteria (algae biru-hijau) adalah penghuni batu yang sangat sering dan dapat menyebabkan warna hitam, kebiruan, atau bahkan noda ungu. Organisme ini di daerah tropis sangat merusak batuan karena adanya musim kemarau dan musim hujan, dimana ketika musim hujan algae akan tumbuh lebat, tetapi ketika musim kemarau algae akan mati, pada puncak musim kemarau algae akan mengelupas. Ketika mengelupas mineral batuan yang ada pada permukaan akan ikut terkelupas pula.

Lichen merupakan tumbuhan yang terbentuk dari simbiosis antara jamur dan algae hijau atau cyanobacterium. Lichen yang paling sering dijumpai berwarna abu-abu, kuning, oranye, hijau atau hitam, dan tidak menunjukkan diferensiasi menjadi batang, akar, dan daun, serta tumbuh di luar ruangan.

Lichen tubuhnya berupatalus dan terbagimenjadi crustose, foliose dan epilithic. Lichen yang dijumpai tumbuh pada permukaan batu kalamba adalah tipe foliose, dimana tubuhnya berupa lembaran-lembaran talus yang berbentuk menyerupai lembaran daun dan berwarna abu-abu dan hijau. Bekas pertumbuhan lichen umumnya mudah dideteksi lewat pola-pola bercak yang tertinggal pada permukaan batuan. Polapola bercak yang tertinggal pada permukaan batuan biasanya akan sangat sulit dihilangkan. Pola-pola tersebut terbentuk karena reaksi antara asam oksalat $\left(\mathrm{H}_{2} \mathrm{C}_{2} \mathrm{O}_{4}\right)$ yang dihasilkan oleh lichen dengan unsur kalsium yang ada pada batuan menjadi kalsium oksalat, dengan reaksi sebagai berikut:

$$
\mathrm{H}_{2} \mathrm{C}_{2} \mathrm{O}_{4}+\mathrm{Ca}^{2+} \longrightarrow \mathrm{CaC}_{2} \mathrm{O}_{4}+2 \mathrm{H}^{+}
$$

Lichen umumnya tumbuh baik pada lingkungan dengan kondisi udara yang cukup bersih, tetapi dipermudah oleh polutan tertentu seperti oksida nitrogen, terutama yang berasal dari polusi kendaraan atau pertanian, sehingga lichen dapat dijadikan sebagai bioindikator adanya polutan pencemar tersebut.

Sekalipun moss yang tumbuh hanya sedikit, tetapi jasad tersebut sangat berbahaya karena moss dapat menyebabkan perubahan mineral batuan menjadi tanah. Moss hanya akan tumbuh pada tempat yang sangat lembab dan berlimpah unsur hara. Oleh karena itu moss lebih banyak tumbuh pada bagian bawah cagar budaya, sebab pada bagian tersebut biasanya berlimpah makanan. Pada awalnya K-feldspar terdekomposisi menjadi kalium bebas 
dan lempung karena reaksi hidrolisis. Kalium bebas yang tersedia pada batuan akan menjadi unsur hara makro (unsur yang dibutuhkan dalam jumlah banyak oleh tumbuhan) bagi moss. Moss yang tumbuh pada batuan memiliki rhizoid yang dapat masuk ke poripori batu sampai kedalaman 2,5 cm. Rhizoid moss akan menciptakan kondisi yang lembab dan asam pada lubang pori, sehingga akan menyebabkan K-feldspar pada batu terdekomposisi menghasilkan K bebas yang dapat diserap oleh moss. Lama kelamaan mineral K-feldspar pada permukaan batuan akan terdekomposisi seluruhnya menjadi tanah, dan akhirnya akan menyerang K-feldspar pada bagian dalam. Jika K-feldspar pada bagian dalam telah terdekomposisi maka batuan menjadi keropos dan rapuh.

\section{Pengelupasan}

Jenis kerusakan yang juga mencolok pada batu kalamba adalah pengelupasan. Dari 24 artefak yang diobservasi, pada 14 artefak mengalami pengelupasan, sekalipun tingkat pengelupasannya berbeda-beda. Pengelupasan adalah proses terkelupasnya atau terlepasnya permukaan batu pada bagian luar yang terekspos atau pada bagian yang terpapar sinar matahari langsung. Jenis atau tipe pengelupasan yang terjadi merupakan tipe scaling (lihat Tabel 3.7). Scaling adalah pelepasan permukaan batu yang tidak mengikuti setiap struktur batu, yang ditandai pelepasan seperti sisik ikan atau sejajar dengan permukaan batu. Scaling merupakan jenis pengelupasan yang sangat bergantung dengan struktur batuan. Ketebalan pengelupasan umumnya dari skala milimeter sampai sentimeter (ICOMOS, 2008: 26). Scaling juga terjadi sebagai efek batu granit yang berada di daerah tropis, dimana curah hujan dan kelembapan udara tinggi.

Scaling merupakan pengelupasan permukaan batu yang disebabkan oleh dekomposisi atau pelapukan mineral feldspar. Hal ini merujuk pada Seri Reaksi Bowen (Gambar 15) bahwa mineralmineral yang terbentuk pada awal pendinginan magma pada suhu dan tekanan tinggi seperti olivine dan feldspar, akan lebih mudah mengalami pelapukan di permukaan dibandingkan mineral yang terbentuk paling akhir yaitu kuarsa yang lebih tahan terhadap pelapukan. Oleh karena itu dugaan penyebab terjadinya scaling karena terdekomposisinya mineral feldspar pada batu granit sangatlah beralasan.

Reaksi kimia yang terjadi dalam proses

Tabel 3.7 Batu kalamba yang mengalami scaling

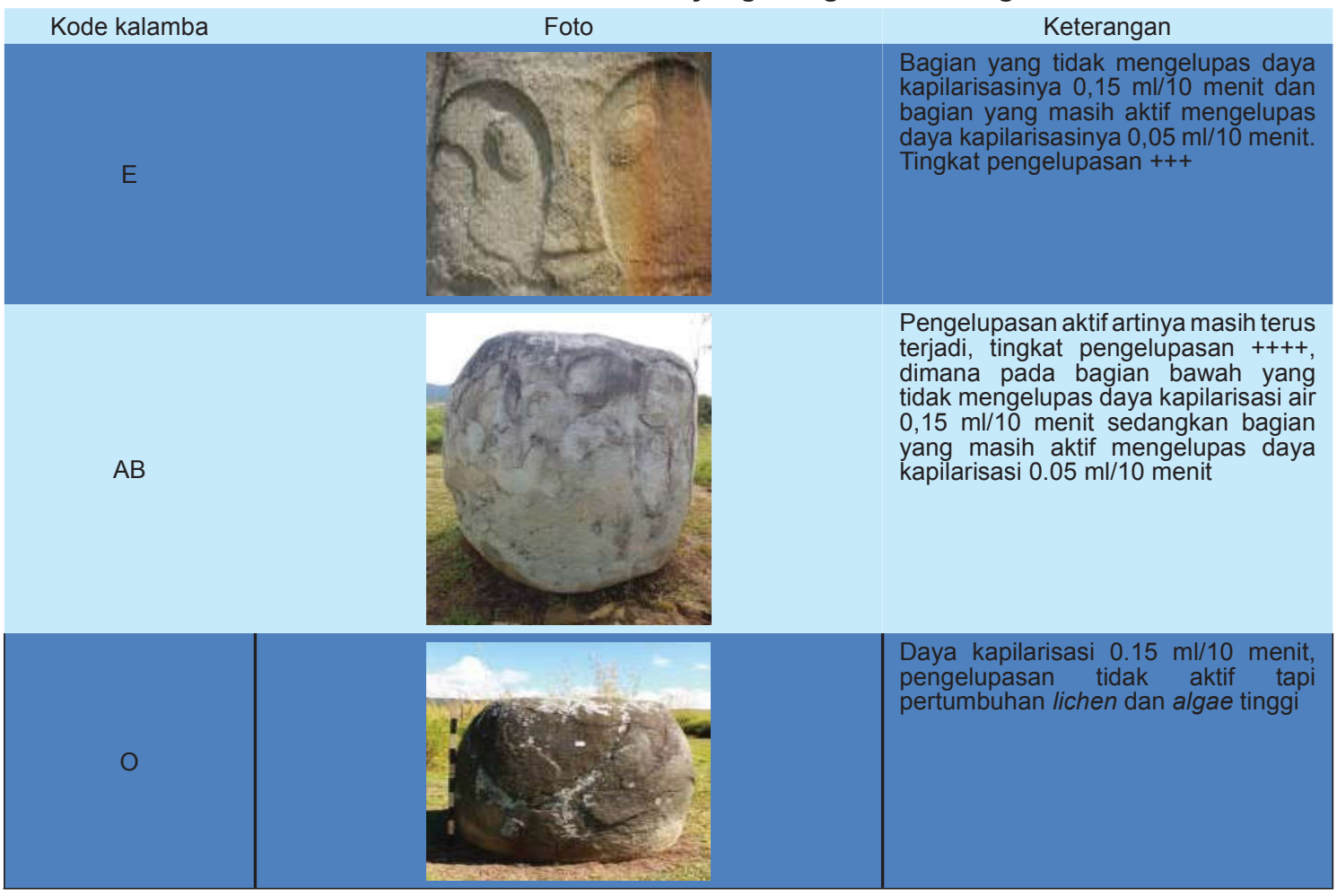




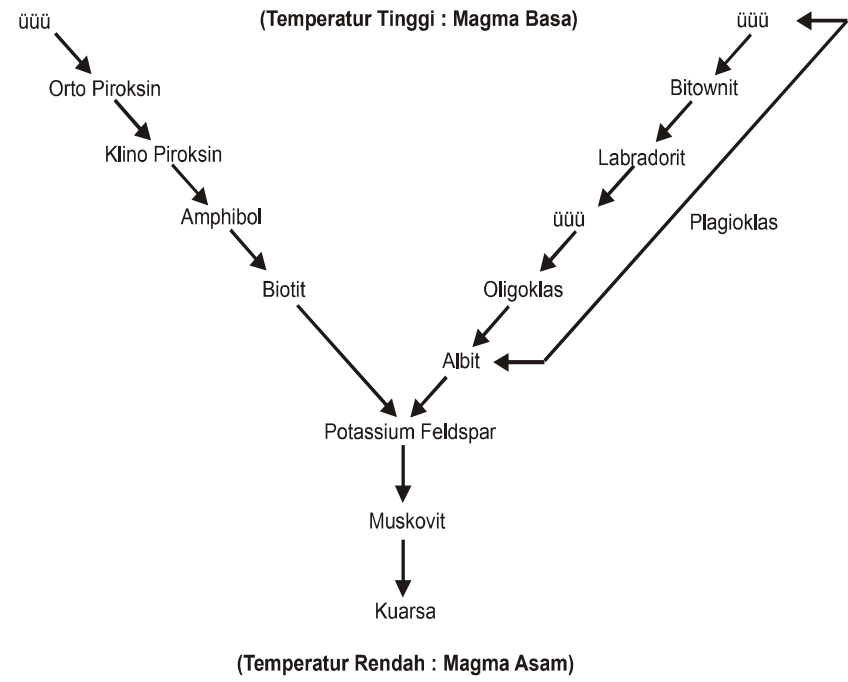

Gambar 15. Pembentukan batuan beku berdasarkan penurunan temperatur

pelapukan atau dekomposisi mineral feldspar menjadi lempung atau clay terjadi melalui proses hidrolisis. Hidrolisis adalah reaksi kimia dimana ion dalam mineral digantikan oleh ion-ion $\mathrm{H}^{+}$dan $\mathrm{OH}^{-}$dalam air. Adapun reaksi kimia proses hidrolisis mineral feldspar sebagai berikut:

1. Reaksi hidrolisis K-feldspar

$2 \mathrm{KAlSi}_{3} \mathrm{O}_{8}+4 \mathrm{H}^{+}+9 \mathrm{H}_{2} \mathrm{O}$

(K-feldspar)

$\mathrm{H}_{4} \mathrm{Al}_{4} \mathrm{Si}_{4} \mathrm{O}_{10}(\mathrm{OH})_{8}+4 \mathrm{H}_{4} \mathrm{SiO}_{2}+4 \mathrm{~K}^{+}$

(kaolinit) (asam silikat alkali/garam)

2. Reaksi kimia Na-feldspar

$2 \mathrm{NaAlSi}_{3} \mathrm{O}_{8}+4 \mathrm{H}^{+}+9 \mathrm{H}_{2} \mathrm{O}$

(K-feldspar)

$\mathrm{H}_{4} \mathrm{Al}_{4} \mathrm{Si}_{4} \mathrm{O}_{10}(\mathrm{OH})_{8}+4 \mathrm{H}_{4} \mathrm{SiO}_{2}+4 \mathrm{Na}^{+}$

(kaolinit) (asam silikat alkali/garam)

Proses pengelupasan pada batu kalamba tidak saja karena proses kimia, tetapi juga mekanisme fisik. Mekanisme fisik proses pengelupasan terjadi karena desakan air yang ada di dalam lubang kalamba ke dinding kalamba. Hal ini didasarkan pada hasil observasi (Tabel 3.7), dimana kalamba yang memiliki daya kapilarisasi $0.05 \mathrm{ml} / 10$ menit mengalami proses pengelupasan aktif yang lebih tinggi dibandingkan dengan batu kalamba yang memiliki daya kapilarisasi 0,1 sampai $0.15 \mathrm{ml} / 10$ menit. Akan tetapi batu yang memiliki daya kapilarisasi di atas $0,20 \mathrm{ml} /$ menit proses pengelupasannya sudah berhenti tetapi batu sudah mulai mengalami kerapuhan dan permukaannya banyak ditumbuhi organisme. Semakin tinggi daya kapilaritas, identik dengan semakin besar atau banyaknya lubang pori pada batuan. Semakin besar daya kapilaritas maka air yang keluar dari dalam lubang kalamba semakin lancar, sehingga permukaan dinding luar kalamba akan semakin lembab yang akan memicu pertumbuhan organisme. Sementara itu semakin kecil daya kapilaritas, air dari dalam kalamba akan semakin sulit keluar, sehingga secara fisik air tersebut akan mendesak dan mendorong dinding kalamba yang menyebabkan terjadinya scaling atau pengelupasan permukaan dinding luar kalamba. Oleh karena itu, pemincu atau penyebab scaling adalah keberadaan air yang ada dalam kalamba, selain karena sifat dari batu granitnya sendiri.

\section{Retak dan Pecah}

Berdasarkan hasil observasi diketahui, dari 24 artefak tinggalan megalitik, 10 buah artefak atau $42 \%$ artefak retak dan 3 buah artefak atau 13\% artefak pecah. Hal ini menunjukkan bahwa tingkat kerusakan retak sangat tinggi. Retak adalah terbentuknya celah pada material batuan, dapat berupa celah yang besar maupun kecil. Retak dan pecah pada batu granit terjadi karena sifat dari struktur mineralnya sendiri yang menjadi ciri dari tipe kerusakan batu granit selain pengelupasan. Menurut Croci (1998: 49), batu granit
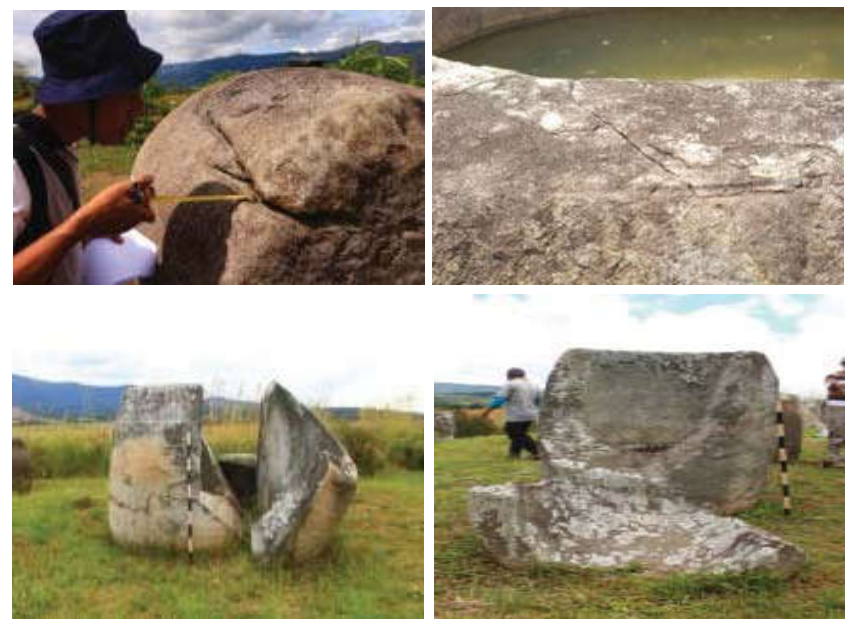

Gambar 16. Artefak batu yang retak dan pecah 
merupakan batu yang tahan terhadap pelapukan akibat cuaca, tetapi beberapa jenis mineral dalam matriksnya sendiri mudah mengalami pelapukan yang lebih besar. Disamping sifat dari batu granit sendiri, retak dan pecah terjadi karena fluktuasi suhu yang tinggi. Sesuai hukum fisika bahwa suatu bahan akan memuai bila dipanaskan dan akan mengkerut bila dingin. Perbedaan suhu siang hari dan malam hari di Situs Pokekea $\left(12,98^{\circ} \mathrm{C}\right)$ sangat tinggi. Kondisi ini menyebabkan mineral batuan memuai dan mengerut. Pada saat siang hari mineral-mineral batuan akan memuai, tetapi kemampuan memuai masing-masing mineral berbeda-beda. Begitu juga saat malam hari dimana temperatur rendah, mineral-mineral batuan akan mengerut, tetapi kemampuan mengerut masing-masing mineral berbeda pula. Kondisi ini menyebabkan ikatan antar mineral atau antar butiran penyusun batuan melemah dan lama kelamaan akan lepas sehingga terjadilah retakan. Retakan lamakelamaan akan semakin besar dan akhirnya mengarah ke pecah.

\section{Endapan atau Kerak yang Berwarna Merah}

Endapan atau kerak yang berwarna merah ditemukan pada dinding luar beberapa batu kalamba. Kerak merah ini sulit sekali dibersihkan atau dikelupas. Berdasarkan hasil observasi diketahui bahwa kerak yang berwarna merah tersebut merupakan oksida besi. Oksida besi tersebut berasal dari pelapukan biotit, seperti sudah dijelaskan di atas bahwa komposisi mineral batu biotit granit terdiri dari feldspar, kuarsa, biotit dan mineral opak. Biotite memiliki rumus kimia $\mathrm{K}(\mathrm{Mg}, \mathrm{Fe})_{3}\left(\mathrm{AlSi}_{3} \mathrm{O}_{10}\right)$ $(\mathrm{OH})_{2}$. Apabila mineral ini bertemu dengan air dan oksigen maka besi akan terlepas dan teroksidasi dari $\mathrm{Fe}^{2+}$ menjadi $\mathrm{Fe}^{3+}$. Bersamaan dengan proses oksidasi terjadi proses hidrasi menghasikan oksida besi bentuk lain yang disebut goethit yang berwarna kekuningkuningan. Goethit akan mengalami proses dehidrasi karena temperatur yang tinggi, sehingga goethit akan kehilangan air menjadi hematit $\left(\mathrm{Fe}_{2} \mathrm{O}_{3}\right)$ yang berwarna merah bata. Oleh karena itu mengapa pada kerak tersebut terdapat warna kekuning-kuningan dan lapisan berwarna merah bata yang tampak lebih tebal. Penjelasan tentang reaksi kimia dekomposisi mineral biotit yang terjadi secara lebih rinci sebagai berikut:

1. Proses oksidasi dan hidrasi biotit menjadi goethit $4 \mathrm{FeO}+2 \mathrm{H}_{2} \mathrm{O}+\mathrm{O}_{2}----->4 \mathrm{FeO} . \mathrm{OH}$ (goethit)

2. Proses dehidrasi goethit menjadi hematit $2 \mathrm{FeO} . \mathrm{OH}$ (goethit) ----- $>\mathrm{Fe}_{2} \mathrm{O}_{3}$ (hematit) $+\mathrm{H}_{2} \mathrm{O}$

Adapun penjelasan mekanisme terjadinya kerak atau endapan yang berwarna merah pada dinding bagian luar pada beberapa batu kalamba dapat dijelaskan sebagai berikut:

1) Ketika hujan maka bagian tengah atau lubang kalamba tersebut akan menampung air hujan.

2) Bersamaan dengan jatuhnya air hujan tersebut, maka air hujan pun dapat mengikat oksigen dari udara, sehingga pada bagian lubang kalamba terdapat air dan oksigen.

3) Adanya air dan oksigen akan menyebabkan oksida besi dalam mineral biotit pada batu yang akan teroksidasi dan terhidrasi menjadi goethit, sehingga pada bagian dalam lubang akan terdapat oksida goethit yang berasal dari pelapukan biotit.

4) Ketika hujan lebat, dimana lubang kalamba sudah tidak dapat menampung air, maka air dalam lubang kalamba akan mengalir keluar dengan membawa goethite.

5) Goethit akan tertinggal dan mengendap pada dinding bekas aliran air.
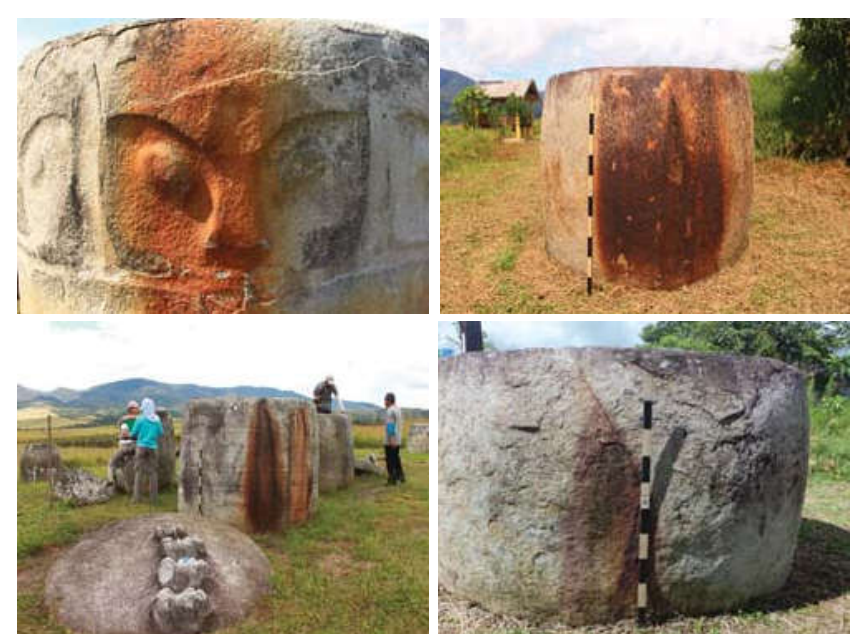

Gambar 17. Kerak atau endapan merah bata yang terdapat pada dinding bagian luar beberapa batu kalamba 
6) Goethit akan mengalami dehidrasi (kehilangan air) menjadi hematit karena air menguap pada suhu yang tinggi. Oleh karena itu endapan atau kerak yang berwarna merah terlihat atau hanya muncul pada bekas aliran air yang mengalir dari lubang kalamba atau pada area aliran air yang keluar dari lubang retakan.

Beberapa batu kalamba pada dinding bagian luarnya terdapat endapan atau kerak yang berwarna merah. Dari 24 artefak yang diobservasi terdapat 4 artefak kalamba yang memiliki kerak berwarna merah pada bagian luarnya (Gambar 17).

\section{Rapuh}

Selama observasi ditemukan 2 artefak batu yang sangat rapuh. Sekalipun jumlah batu rapuh hanya sedikit tetapi adanya artefak batu yang rapuh menunjukkan sudah terjadi pelapukan tingkat lanjut. Gejala kerapuhan pada batuan dapat ditunjukkan dengan tingkat kekerasan batu yang rendah dibandingkan dengan jenis batu yang sama serta gejala sanding. Sanding ditandai jika permukaan batu disentuh maka akan terdapat butiran pasir yang menempel, atau jika digores maka akan terdapat butiran pasir yang rontok.

Kerapuhan pada batu granit disebabkan oleh lepasnya ikatan antar mineral secara merata atau menyeluruh. Ikatan antar mineral lepas karena proses dekomposisi pada beberapa jenis mineral seperti feldspar dan biotit. Dekomposisi mineral terutama disebabkan oleh reaksi oksidasi dan hidrolisis yang dipicu oleh keberadaan air. Hal ini dibuktikan pada beberapa batu kalamba yang diobservasi, kekerasan batu pada bagian bawah selalu lebih rendah dibandingkan bagian atas. Karena bagian bawah selalu bersentuhan dengan tanah dan terjadi kapilarisasi air, serta air dalam lubang kalamba akan cenderung turun ke bawah karena gaya gravitasi.

\section{PEMBAHASAN DAN PENANGANAN KONSERVASI}

\section{A. Pembahasan}

Berdasarkan penjelasan pada bab sebelumnya tentang jenis kerusakan pada artefek-artefak tinggalan megalitik di Situs Pokekea yang terdiri dari pertumbuhan organisme, pengelupasan, kerak merah, retak, pecah dan rapuh, jenis kerusakan dan pelapukan tersebut terutama disebabkan oleh proses fisik dan kimiawi. Faktor penyebab utama dari proses tersebut adalah adanya air dalam lubang kalamba dan fluktuasi suhu dan kelembaban udara yang cukup tinggi. Usaha untuk menangani kerusakan dan pelapukan yang terjadi pada tinggalan megalitik di Situs Pokekea dapat menggunakan metode preventive conservation dan active conservation. Preventive conservation adalah usaha untuk mencegah kerusakan dan pelapukan lebih lanjut melalui pemeliharaan rutin, mengendalikan suhu dan kelembaban udara di sekitar batu, mengontrol polusi udara, dan lain sebagainya. Sedangkan active conservation adalah

Tabel 8 Batu kalamba yang rapuh

Kode $\begin{aligned} & \text { Keterangan } \\ & \text { Museum Negeriamba balu, kekerasan di } \\ & \text { pada bagian bawah } 1 \text { dan pada } \\ & \text { bagian tengah dan atas } 2 \text { skala } \\ & \text { mosh. Karena tingkat kerapuhan } \\ & \text { yang tinggi maka ketebalan dinding } \\ & \text { kalamba semakin lama semakin } \\ & \text { menipis }\end{aligned}$


penanganan konservasi untuk merestorasi kerusakan dan pelapukan yang telah terjadi pada tinggalan megalitik di Situs Pokekea.

\section{B. Preventive Conservation}

Usaha yang dapat dilakukan untuk mencegah kerusakan dan pelapukan lebih lanjut dapat dilakukan dengan beberapa cara, antara lain:

a. Menghilangkan air dari dalam lubang kalamba

Air merupakan penyebab utama terjadinya kerusakan dan pelapukan pada tinggalan megalitik di Situs Pokekea, selain karena faktor fluktuasi cuaca. Oleh karena itu usaha yang dilakukan tentu bertujuan untuk mengurangi atau menghilangkan air pada lubang kalamba. Penghilangan air dilakukan dengan membuang air hujan secara rutin setelah turun hujan. Tetapi kegiatan ini harus dilakukan dengan metode yang tepat sehingga tidak merusak artefak-artefak tersebut. Perlu dicarikan teknik yang tepat untuk membuang air dari lubang kalamba tanpa merusak kalamba-kalamba tersebut. Balai Pelestarian Cagar Budaya Gorontalo telah menempatkan 4 orang juru pelihara pada Situs Pokekea, sehingga juru pelihara tersebut dapat dilatih untuk membantu membuang air hujan yang tertampung pada lubang kalamba tanpa beresiko menyebabkan kerusakan pada kalamba.

Usaha untuk mencegah masuknya air dalam lubang kalamba dapat pula dilakukan dengan pemasangkan kembali tutuna (penutup) ke kalamba. Tetapi pemasangan kembali tutuna pada pasangannya harus mempertimbangkan aspek arkeologi, apakah cara tersebut dapat diterima atau tidak. Pertimbangan dari sisi dimensi ukuran kalamba dan tutuna serta kemampuan batu kalamba untuk menahan beban tutuna juga harus dipertimbangkan.

\section{b. Menjaga iklim mikro lingkungan agar stabil}

Kondisi lingkungan di Situs Pokekea sangat fluktuatif, sehingga sangat beresiko mempercepat proses kerusakan dan pelapukan batu kalamba. Usaha yang dapat dilakukan untuk mengurangi fluktuasi suhu dan kelembaban adalah menstabilkan suhu dan kelembaban udara dengan penanaman vegetasi pohon pelindung. Vegetasi pohon ini akan menciptakan iklim mikro yang stabil sehingga dapat mengurangi fluktuasi suhu dan kelembaban yang tinggi, yang pada akhirnya akan memperlambat proses kerusakan dan pelapukan artefak batu di Situs Pokekea.

\section{c. Pemasangan shelter}

Shelter berasal dari Bahasa Inggris yang berarti tempat tinggal atau tempat berteduh, perlindungan, penutup dan lain-lain. Istilah shelter dapat disamakan dengan istilah cungkup dalam Bahasa Indonesia. Menurut kamus besar Bahasa Indonesia, cungkup berarti bangunan beratap di atas makam sebagai pelindung makam. Di Indonesia istilah cungkup juga digunakan untuk bangunan beratap tidak berdinding yang berfungsi untuk melindungi artefak cagar budaya dari hujan dan sinar matahari langsung. Menurut Doehne dan Price (2010), pemasangan shelter sebenarnya termasuk dalam preventive conservation. Pemasangan shelter bertujuan mengurangi jumlah air hujan yang mencapai batu dan menstabilkan suhu dan kelembaban batu. Tetapi tindakan ini dapat dianggap sebagai visual pollution atau polusi pemandangan karena akan merusak pemandangan asli dari situs, kecuali untuk artefak-artefak yang sudah tidak in situ, misalnya untuk beberapa artefak yang sudah dipindah ke Museum Negeri Palu. Oleh karena pemasangan shelter pada tinggalan megalitik yang masih in situ harus melalui pertimbangan yang matang terutama dari aspek arkeologi.

Usaha-usaha pencegahan kerusakan dan pelapukan di atas merupakan alternatif-alternatif pilihan penanganan. Sebelum menerapkannya perlu dilakukan kajian lebih lanjut untuk menentukan metode yang tepat. Penentuan metode tidak

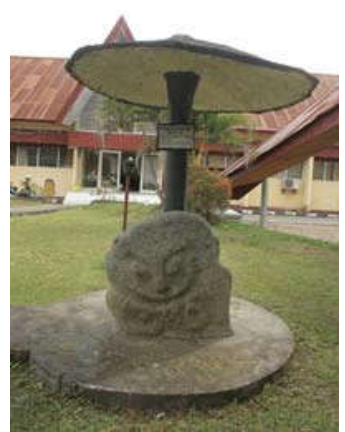

Gambar 18. Shelter atau cungkup pada artefak di Museum Negeri Palu 
hanya mempertimbangkan dari aspek teknis, dalam hal ini konservasi tetapi juga dari aspek arkeologis, sehingga usaha penanganan apapun dapat dipertanggungjawabkan secara ilmiah.

\section{Active Conservation}

Jenis kerusakan dan pelapukan yang terjadi pada artefak di Situs Pokekea adalah pengelupasan atau scaling, pertumbuhan moss, algae dan lichen, retak, pecah, kerak merah, serta rapuh. Tetapi tidak semua jenis kerusakan dan pelapukan dapat dilakukan tindakan konservasi. Kerak atau endapan yang berwarna merah merupakan oksida besi. Saat ini belum ditemukan metode atau cara yang tepat untuk menanganinya. Sifat dari endapan merah tersebut sangat keras, melekat kuat pada permukaan batu atau terikat kuat dengan mineral-mineral batuan yang ada di permukaan batu, sehingga bahan kimia yang bersifat asam keraspun akan sulit membersihkan. Justru penggunaan bahan kimia yang bersifat asam kuat dikawatirkan dapat merusak batunya sendiri. Sementara itu jenis kerusakan dan pelapukan yang lain seperti pengelupasan, retak, pecah, rapuh dan pertumbuhan organisme dapat dilakukan tindakan konservasi sebagai berikut:

\section{a. Pertumbuhan organisme}

Organisme yang sangat berbahaya terhadap batuan tinggalan megalitik adalah moss atau lumut. Karena lumut dapat mendekomposisi mineral batuan menjadi tanah. Sekalipun lichen dan algae juga dapat menyebabkan hal yang sama, tetapi efek merusak moss lebih besar dibandingkan keduanya. Oleh karena itu diperlukan tindakan untuk mencegah dan membunuh pertumbuhan organisme tersebut. Diperlukan biocide yang tidak hanya membunuh organisme, tetapi biocide tersebut diharapkan mampu membuat batu resisten terhadap pertumbuhan kembali dan hadirnya strain baru. Biocide tersebut seharusnya tidak berbahaya terhadap batunya sendiri dan tidak menyebabkan perubahan penampilan. Biocide tersebut juga seharusnya tidak tercuci oleh air hujan dan terdegradasi oleh sinar ultraviolet sebelum memberikan efek serta aman untuk orang yang mengaplikasikanya dan tidak berbahaya terhadap lingkungan secara luas (Doehene and Price, 2010:
47). Akhir-akhir ini telah dilakukan penelitian biocide yang dapat membuat permukaan batu resisten terhadap pertumbuhan organisme. Biocide tersebut berbahan dasar $\mathrm{Cu}$ dan $\mathrm{Zn}$, dengan konsentrasi yang sangat rendah dan hanya dengan sekali aplikasi dapat membuat batu resisten sampai 10 tahun. Akan tetapi bahan tersebut belum beredar di Indonesia, sehingga belum dapat diaplikasikan. Untuk mengaplikasikan bahan tersebut harus melalui proses pengujian terlebih dahulu. Di Indonesia saat ini digunakan biocide berbahan dasar lithium bromasil untuk membunuh jasad moss dan algae pada material cagar budaya, tetapi daya hambat bahan ini terhadap pertumbuhan kembali tidak lebih dari dua tahun. Untuk sementara waktu penggunaan biocide berbahan dasar lithium bromasil dapat direkomendasikan.

\section{b. Pengelupasan}

Pengelupasan merupakan jenis pelapukan yang banyak dijumpai pada artefak kalamba di Situs Pokekea. Penyebab utama pelapukan tersebut adalah air, sehingga penanganan lebih ditekankan pada menghilangkan penyebab tersebut, seperti yang telah dijelaskan pada sub bab pembahasan. Teknik untuk penanganan konservasi pada pengelupasan saat ini secara umum adalah dengan cara menempelkan kembali batu yang mengelupas dengan epoksi resin. Metode ini dilakukan pada kasus pengelupasan dengan fragmen kecil. Metode ini tentu tidak cocok bila diterapkan pada kasus pengelupasan dimana material yang terkelupas berupa fragmen-fragmen berukuran besar (lihat Gambar 19). Oleh karena itu perlu kiranya dilakukan kajian untuk menentukan metode atau teknik yang tepat untuk penanganan

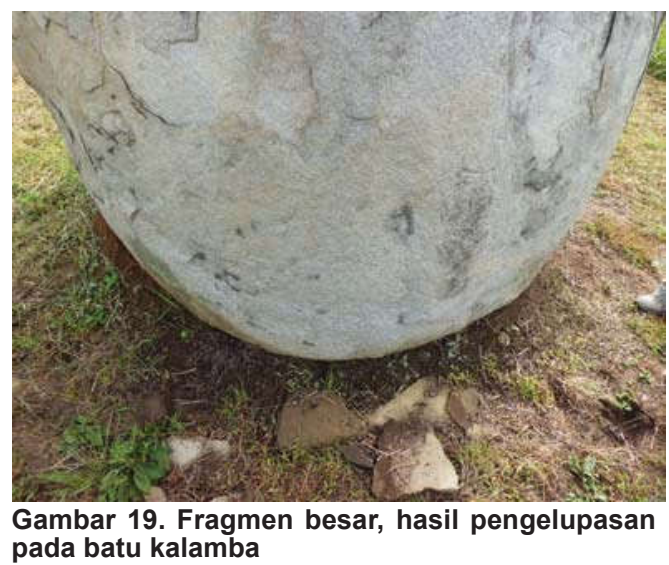


pengelupasan.

\section{c. Retak}

Retak yang terjadi pada artefak di Situs Pokekea berupa retak mikro dan retak makro. Penanganan kedua jenis retakan tentu berbeda antara makro dan retak mikro. Tindakan konservasi untuk retak mikro dapat dilakukan dengan mengisi celah retakan menggunakan filler atau bahan pengisi. Bahan pengisi dapat berupa bubukan batu sejenis yang ditambah dengan bahan lain yang bersifat mengikat butiran batu dan ditambah etil silica. Komposisi persisnya campuran tersebut masih memerlukan penelitian lebih lanjut agar filler yang diaplikasikan memiliki warna dan sifat yang tak jauh dari sifat batunya. Sementara itu tindakan konservasi untuk batu kalamba yang retak makro, dimana retakan tersebut telah mengarah ke pecah maka dilakukan dengan memasukan material penyambung yang berbahan fiber dan epoksi resin pada kedua bagian artefak yang akan pecah tersebut (terilustrasikan pada Gambar 20). Kemudian pada celah diisi dengan bahan filler atau mortar kembali. Oleh karena itu diperlukan penelitian lanjutan untuk menentukan diameter fiber, komposisi filler atau mortar pada skala laboratorium dan dilanjutkan prediksi aplikasi di lapangan.

\section{d. Pecah}

Tindakan konservasi yang dapat dilakukan pada artefak yang pecah adalah dengan penyambungan kembali menggunakan angkur berbahan fiber (Gambar 21) dan direkatkan dengan epoksi resin

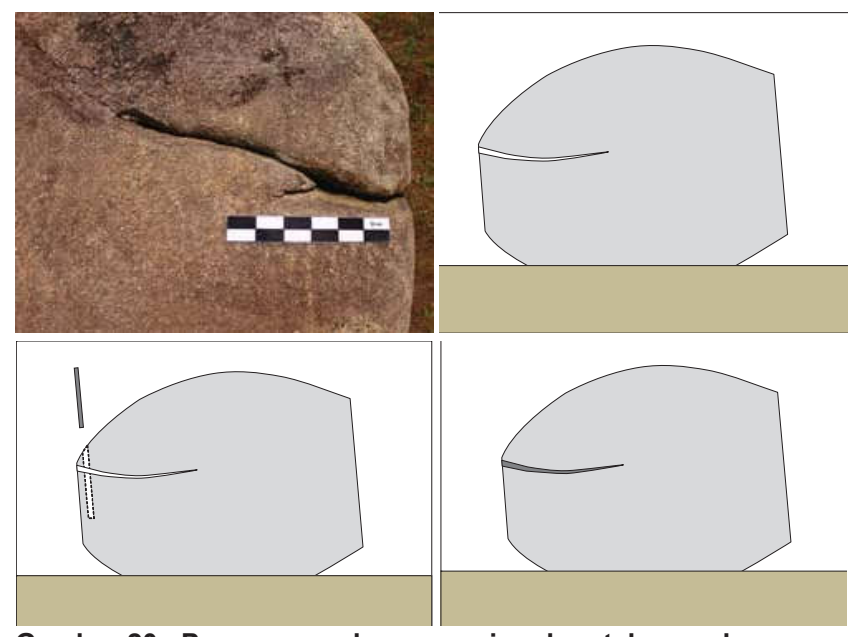

Gambar 20. Penanganan konservasi pada retakan makro

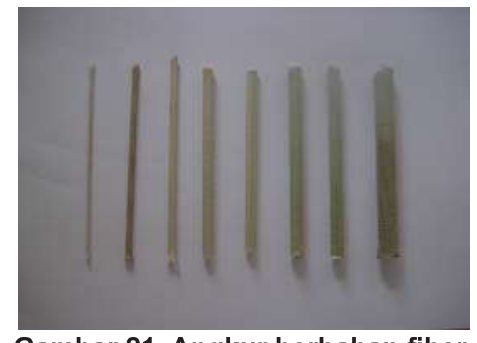

Gambar 21. Angkur berbahan fiber
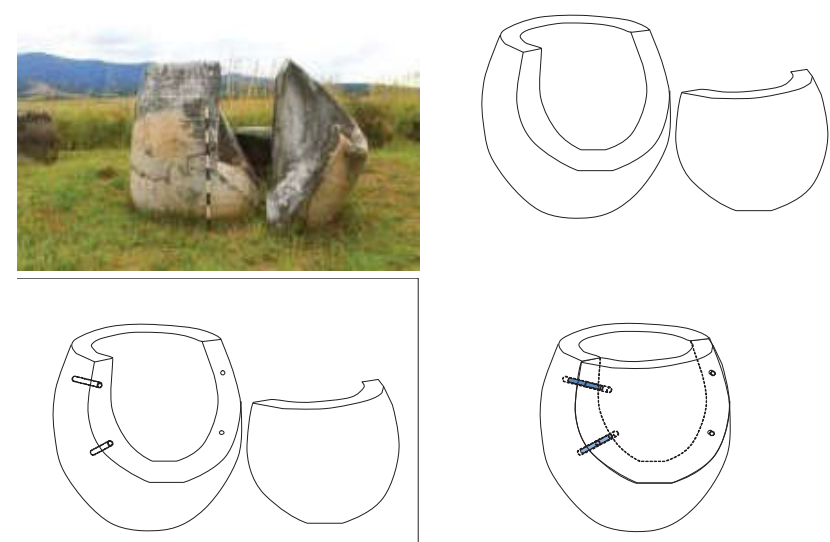

Gambar 22. Ilustrasi teknik penyambungan artefak kalamba yang pecah menggunakan angkur dari kiri ke kanan

yang dicampur dengan furmed silica atau cabosil atau aerosol. Pemberian bahan furmed silica atau carbosil atau aerosol berfungsi untuk lebih memadatkan epoksi resin, sehingga epoksi resin tidak akan mengalir ke permukaan kalamba. Celah pada sambungan dapat diisi dengan mortar atau filler yang berbahan dasar bubukan batuan yang sejenis.

Teknis penyambungan artefak kalamba yang pecah terilustrasi pada Gambar 22. Oleh karena itu diperlukan penelitian lanjutan untuk menentukan diameter fiber, dan komposisi mortar serta ukuran butiran furmed silica.

e. Rapuh

Artefak batu yang rapuh dapat diperkuat kembali mengunakan bahan konsolidan (consolidant) berbahan dasar etil silikat. Bahan tersebut telah dikembangkan sebagai bahan konsolidan batu sejak tahun 1980-an. Aplikasi pertama tahun 1987 pada batu pasir dan monumen di Perancis menunjukkan batu yang sebelumnya telah sangat rapuh, tetap kuat setelah 25 tahun aplikasi Akan tetapi etil silica sebagai bahan konsolidan memiliki kelemahan karena etil silica tidak dapat diaplikasikan pada batu yang basah dengan kondisi kelembaban lingkungan 


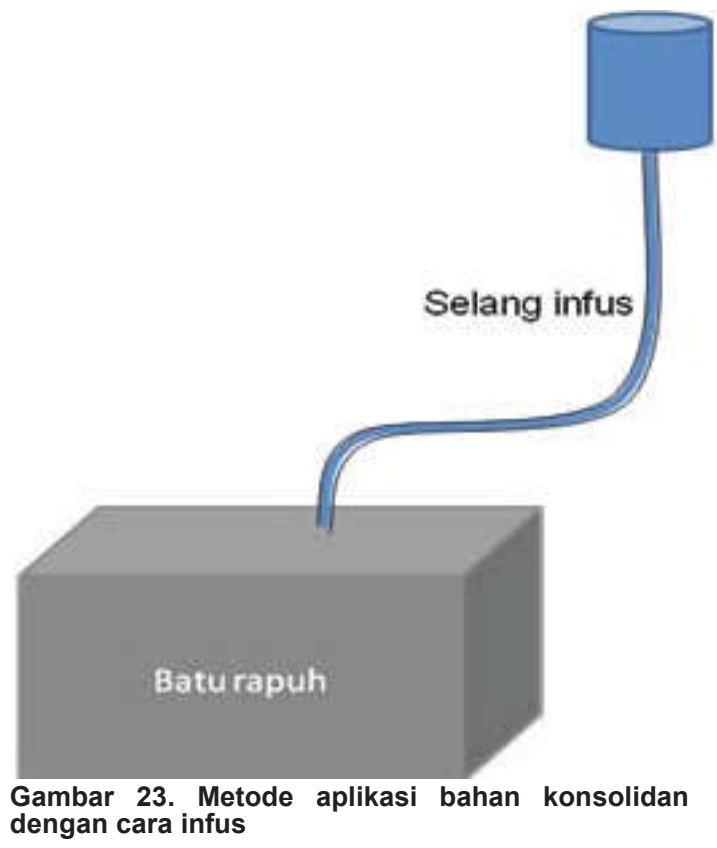

tinggi, serta batu yang mengandung kalsit dan garam terlarut. Dengan kelemahan-kelemahan tersebut, saat ini telah dikembangkan bahan konsolidan berbahan dasar lithium silica yang dapat diaplikasikan pada batu basah serta pada batu yang mengandung kalsit dan garam terlarut (Thorn, 2012). Metode aplikasi dapat dilakukan dengan cara diinfus (seperti terilustrasi pada Gambar 23) direndam dan dioles. Cara yang dipilih tergantung dari bentuk, ukuran dan kondisi kalamba. Oleh karena itu untuk mengaplikasikan etil silica maupun lithium silica memerlukan pengujian atau eksperimen terlebih dahulu baik dari skala laboratorium yang dilanjutkan ke skala lapangan. Eksperimen ini untuk memastikan kecocokan bahan konsolidan dengan jenis batuan yang ada di Situs Pokekea serta untuk menentukan metode aplikasinya.

\section{KESIMPULAN, SARAN DAN REKOMENDASI}

\section{A. Kesimpulan}

a. Jenis tinggalan megalitik di Situs Pokekea didominasi batu kalamba dan sejumlah kecil arca serta menhir.

b. Kondisi lingkungan di Situs Pokekea berupa lembah padang ilalang yang memiliki iklim mikro yang sangat fluktuatif.

c. Hasil analisis petrografi menunjukan jenis batuan tinggalan megalitik berupa biotite granite, dengan komposisi mineral terdiri dari feldspar (plagioklas dan K-feldspar), kuarsa, biotit, dan mineral opak.

d. Hasil analisis fisik menunjukan terdapat jenis batu biotit granit yang masih bagus dan batu biotit granit yang telah lapuk.

e. Posisi 24 artefak yang diobservasi menunjukan 18 buah artefak berada posisi berdiri di permukaan tanah dan terbenam sebagian dalam tanah, serta 6 artefak lainnya berada pada posisi miring atau tidur.

f. Jenis kerusakan dan pelapukan yang dijumpai pada artefak-artefak tinggalan megalitik di Situs Pokekea berupa endapan atau kerak berwarna merah, pengelupasan (scaling), retak, pecah, batu yang rapuh, dan batu yang ditumbuhi jasad algae, lichen, dan moss.

g. Kerak merah merupakan oksida besi yang berasal dari pelapukan biotit. Dekomposisi kimia mineral biotit disebabkan oleh proses oksidasi dan hidrasi biotit menjadi goethit, dilanjutkan proses dehidrasi goethit menjadi hematit.

h. Dari 24 artefak yang diobservasi, 14 artefak mengalami pengelupasan dengan tingkat pengelupasan yang berbeda-beda. Tipe pengelupasan berupa tipe scaling yang disebabkan oleh dekomposisi mineral feldspar menjadi lempung atau clay melalui proses hidrolisis.

i. Dari 24 artefak tinggalan megalitik, 10 buah artefak atau $42 \%$ artefak retak dan 3 buah artefak atau $13 \%$ artefak pecah. Retak dan pecah disebabkan sifat dari batu granit sendiri, dan terjadi karena fluktuasi suhu yang tinggi.

j. Dari 24 artefak yang diobservasi, 2 artefak batu sangat rapuh. Kerapuhan pada batu granit disebabkan oleh lepasnya ikatan antar mineral secara merata atau menyeluruh akibat proses dekomposisi oleh reaksi oksidasi dan hidrolisis yang dipicu oleh keberadaan air.

k. Hampir seluruh permukaan artefak batu pada tinggalan megalitik di Situs Pokekea ditumbuhi organisme. Jenis organisme yang dijumpai tumbuh pada permukaan batu adalah algae, lichen dan moss.

1. Proses kerusakan dan pelapukan tinggalan megalitik di Situs Pokekea disebabkan oleh sifat 
batu granit sendiri, keberadaan air, fluktuasi suhu dan kelembaban udara yang tinggi.

m. Usaha untuk menangani kerusakan dan pelapukan pada tinggalan megalitik di Situs Pokekea dapat menggunakan metode preventive dan active conservation.

\section{B. Saran}

Perlu dilakukan kajian lanjutan antara lain:

a. Penelitian arkeologi untuk mengembalikan kalamba pada posisi semula dan pemasangan tuntuna dengan pasangan kalambanya.

b. Kajian untuk menentukan jenis tumbuhan yang tepat guna menjaga iklim mikro supaya stabil.

c. Kajian untuk menentukan metode konsolidasi batu kalamba menggunakan bahan konsolidan berbahan dasar etil silica dan lithium silica.

d. Kajian untuk menentukan metode penyambungan batu kalamba.

e. Kajian penanganan retakan untuk menentukan diameter fiber, komposisi filler atau mortar

f. Kajian untuk menentukan metode yang tepat untuk

\section{DAFTAR PUSTAKA}

\section{Literatur/Textbook}

Anonim. 2010. Undang-Undang Nomor 11 Tabun 2010 tentang Cagar Budaya.

Anonim. 2011. Kamus Besar Bahasa Indonesia. Edisi ke-4. Departemen Pendidikan Nasional. Jakarta.

Croci, Giorgio. 1998. The Conservation and Structural Restoration of Architectural Heritage. Computational Mechanics Publications Southampton, UK and Boston, USA

Doehene and Price. 2010. Stone Conservation: An Overview of Current Research. The Getty Conservation Institute, Los Angles.

ICOMOS International Scientific Committee for Stone (ISCS). 2008. Illustrated Glossary on Stone Deterioration Patterns. Ateliers 30 Impression, Champigny/Marne, France penanganan pengelupasan.

g. Kajian konservasi untuk menentukan bahan herbisida yang tepat untuk mencegah pertumbuhan organisme pada batu kalamba

\section{Rekomendasi}

Usaha yang dapat dilakukan untuk mencegah kerusakan dan pelapukan lebih lanjut adalah penghilangan air dengan membuang air pada lubang Tkalamba secara rutin setelah hujan, dan menutup kalamba dengan tutuna jika memungkinkan dari tinjauan arkeologi. Sementara itu tindakan konservasi dapat dilakukan adalah penanganan retak makro dan mikro, batu yang rapuh, dan pertumbuhan organisme. Pencegahan pertumbuhan organisme untuk sementara waktu dapat digunakan bahan biocide berbahan dasar lithium bromasil. Semua tindakan konservasi yang akan dilaksanakan harus didahului penelitian konservasi terlebih dahulu.

Suharyadi. 1984. Geologi Teknik untuk Teknik Sipil. Fakultas Teknik, Universitas Gadjah Mada, Yogyakarta.

Sutanto, Rachman. 2005. Dasar-Dasar Ilmu Tanah, Konsep dan Kenyataan. Kanisius, Yogyakarta.

Publikasi Hasil Penelitian, Skripsi, Tesis dan Artikel Anonim. 2009. Stone Cleaning: Guedance, Design and Conservation, Masterplanning, Design and Conservation. Enterprice, Planing and Infrastructure. www. Aberdeencity.gov.uk Ramadhanil P, Kessler, P J A, S R Gradstein, Guhardja E., Leuschner C.H., Wiriadinata H., Sudirdjo S. T. 2002. Tree Composition In Secondary Forest of Lore Lindu National Park Central Sulawesi, Indonesia. Symposium (SFB 552) " Land Use, Nature Conservation and 
the Stability of Rainforest margins in Southeast Asia. Bogor. 29 September- 3 October 2002

Setiadji, P. 2006. Karakteristik Derajat Pelapukan Andesit dan Prilaku Geomekanikannya di Purwakarta. Program Studi Teknik Geologi. Fakultas Ilmu Kebumian dan Teknologi Mineral. Institut Teknologi Bandung.

Soeroso. 2007. Pengelolaan Warisan Budaya Dunia di Indonesia. Makalah Bimbingan Teknis Pengelolaan Situs Warisan Dunia. Borobudur, 3-7 September 2007.

Sukendar, Haris. 1997. Album Tradisi Megalitik di Indonesia. Proyek Pengembangan Media Kebudayaan, Direkrorat Jenderal Kebudayaan, Departemen Pendidikan dan Kebudayaan, Jakarta.

Swastikawati, Ari. 2011. Teori Konservasi Kayu. Makalab; disampaikan dalam Pelatihan Tenaga Teknis Konservasi Tingkat Menengah, Balai Konservasi Peninggalan Borobudur. Direktorat Jenderal Sejarah dan Purbakala, Kementerian Kebudayaan dan Pariwisata pada tanggal 25 Juli sampai 13 Agustus 2011

Thorn, Andrew. 2012. Lithium Silicate Consolidation of Wet Stone and Plaster. 12th International Congress on the Deterioration and Conservation of Stone, Thursday 25 October 2012. Methods and Materials of Cleaning, Conservation, Repair and Maintenance Session XII: 8:00 - 10:00

\section{Website}

http://www.uni-kiel.de/ufg/bereiche/ dateienJMueller/16 Kirleis et al. Crossing Borders 16.pdf. Kirleis, W., Müller, J., Kortemeier, C., Behling, H., and Soeghondo, S. 2012. The Megalithic Landscape of Central Sulawesi, Indonesia: Combining Archaeological and Palynological Investigations

http://epri-wismark.blogspot.com/Megalitikum dikutip tanggal 13 Mei 2013

http://id.wikipedia.org/wiki/Andesit, dikutip tanggal 15 Mei 2013

http://www.volcanodiscovery.com/id/glossary/ andesite.html, dikutip tanggal 15 Mei 2013)

http://future20.wordpress.com/2013/03/08/ jenis-jenis-batuan-ciri-ciri-dan-prosesterbentuknya/, dikutip tanggal 15 Mei 2013 http://www.google earth. 2013 